\title{
Evaluating the Trade Effect of Developing Regional Trade Agreements: A Semi-parametric Approach
}

\author{
Souleymane Coulibaly \\ World Bank ${ }^{*}$ \\ 1818 H Street NW, 20433 Washington DC, USA \\ Tel: +1 2024739845 \\ Email: scoulibaly2@worldbank.org
}

\begin{abstract}
Many recent papers have pointed to ambiguous trade effects of developing regional trade agreements (RTAs), calling for a reassessment of their economic merits. We focus on seven such agreements currently in force in Sub-Saharan Africa (ECOWAS and SADC), Asia (AFTA and SAPTA) and Latin America (CACM, CAN and MERCOSUR), estimating their impacts on their members' trade flows. Instead of the usual dummy variables for RTAs, we propose a variable taking into account the number of years of membership. We then combine a gravity model with kernel estimation techniques so as to capture the non-monotonic trade effects while imposing minimal structure on the model.

The results indicate that except for SAPTA, all these RTAs have had a positive impact on their members' intra-trade over the estimation period (1960-1999). AFTA seems to be the most successful among them with an estimated positive impact on its members' imports from the rest of the world (ROW), but its impact on their exports to the ROW is rather limited. During its first ten years of existence, ECOWAS appears to have had a positive impact on its members' imports from the ROW, but this positive impact vanished over time. SAPTA's negative impact on its members' intra-trade is probably an implicit effect of the India-Pakistan tensions over the estimation period.
\end{abstract}

J.E.L Classification: F11, F15, O50

Keywords: regional trade agreement, kernel regression, trade impact

World Bank Policy Research Working Paper 4220, May 2007

The Policy Research Working Paper Series disseminates the findings of work in progress to encourage the exchange of ideas about development issues. An objective of the series is to get the findings out quickly, even if the presentations are less than fully polished. The papers carry the names of the authors and should be cited accordingly. The findings, interpretations, and conclusions expressed in this paper are entirely those of the authors. They do not necessarily represent the view of the World Bank, its Executive Directors, or the countries they represent. Policy Research Working Papers are available online at http://econ.worldbank.org.

Acknowledgments: I thank Jeffrey Bergstrand, Paul Brenton, Marius Brülhart, Celine Carrère, Renato Flores, Lionel Fontagné, Guillaume Gaulier, Thierry Mayer, Daniel Mirza, Eric Toulemonde and an anonymous referee for helpful comments and suggestions. 


\section{Introduction}

According to official rhetoric, countries involved in a regional trade agreement (RTA) expect a welfare gain. This expectation is so strong that most engage in many different agreements leading to what Bhagwati called the "spaghetti bowl" phenomenon, that is the crisscrossing of many regional agreements differing in their schedules of phasing out tariffs, rules of origin and excluded products. Recent studies of trade effects of developing RTAs come to different conclusions, sometimes for the same RTAs, as depicted in Table 1.

Table 1: Trade impact of some developing RTAs

\begin{tabular}{|c|c|c|}
\cline { 2 - 3 } \multicolumn{1}{c|}{} & Net trade creation & Net trade diversion \\
\hline AFTA/ASEAN & Carrère (2004) & Dee \& Gali (2003) \\
& $\begin{array}{c}\text { Elliott \& Ikemoto (2004) } \\
\text { Gosh \& Yamarik (2004) } \\
\text { Soloaga \& Winters (2000) }\end{array}$ \\
\hline LAFTA/LAIA & Cernat (2001) & \\
& Dee \& Gali (2003) & Carrère (2004) \\
& Goloag \& Yamarik (2004) & Soloaga \& Winters (2000) \\
\hline MERCOSUR & Gosh \& Yamarik (2004) & Carrère (2004) \\
& Cernat (2001) & Dee \& Gali (2003) \\
& Soloaga \& Winters (2000) & Krueger (1999) \\
\hline
\end{tabular}

For instance, AFTA, LAIA and MERCOSUR appear to have been net trade creating in some studies and net trade diverting in others. These studies use different estimation methods, different databases and different dynamic specifications to measure trade effects, and they focus on the number of years these RTAs have existed to estimate their trade impact.

Freund and McLaren (1999) introduced an alternative way of looking at RTAs trade effect by focusing on the dynamic of trade orientation when a country joins a regional trade agreement and over the number of years of membership. This paper follows this idea of evaluating the participation effect of each RTA's member. To carry out such analysis, we propose an RTA variable taking into account the number of years of participation of each member, and we use a two-step estimation approach combining a gravity model estimation and a kernel regression of the estimated trade residuals. We focus on seven developing RTAs covering Sub-Saharan Africa (ECOWAS and SADC), Asia (AFTA and SAPTA) and Latin America (CACM, CAN and MERCOSUR) over the period 1960-1999. ${ }^{1}$

The results indicate that except for SAPTA, all these RTAs have had a positive impact on their members' intra-trade over the estimation period (1960-1999). AFTA

\footnotetext{
${ }^{1}$ Appendix 1 describes these RTAs.
} 
seems to be the most successful among them with an estimated positive impact on its members imports from the ROW (hence no trade diversion), but its impact on their exports to the ROW is rather limited. During its first ten years of existence, ECOWAS appears to have had a positive impact on its members imports from the ROW (hence no trade diversion), but this positive impact vanished over time. SAPTA's negative impact on its members' intra-trade is probably an implicit effect of the India-Pakistan tensions over the estimation period.

The remainder of the paper contains a theoretical and an empirical part. In the theoretical part (section 2), we first describe the RTA variable, then we present the twostep estimation approach. In the empirical part (section 3), we estimate and discuss the trade effect of the selected developing RTAs. Section 4 concludes the paper.

\section{Theoretical investigation}

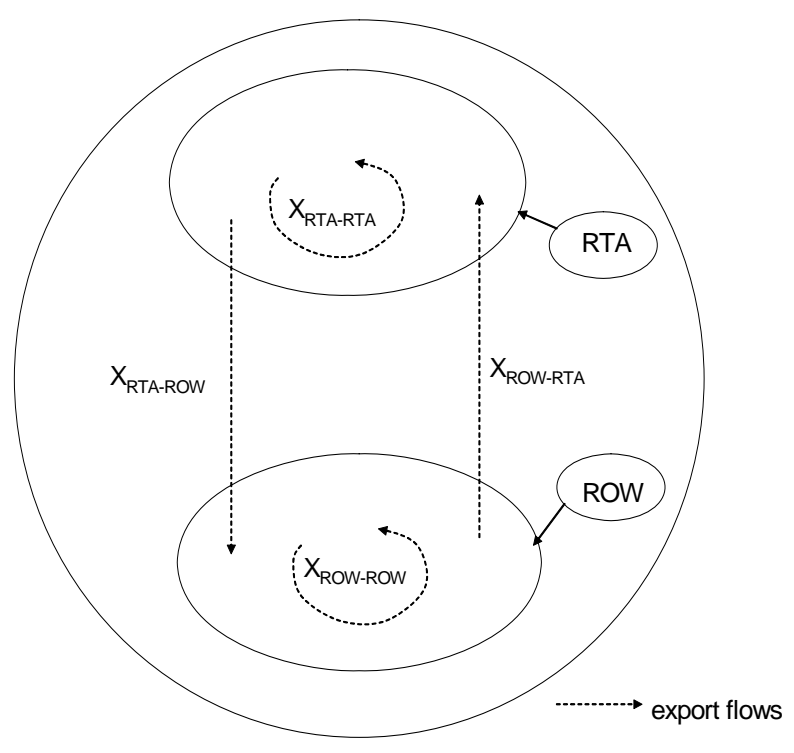

Figure 1: Geography of World Trade Flows

To properly measure the RTAs' trade effect, we focus on export flows of the trading partners in a general equilibrium framework as described in Figure 1. The subset RTA comprises the member countries of one of the seven RTAs under consideration and the subset ROW represents all the remaining countries in the world.

\subsection{The RTA variable}

The usual RTA's dummy variable assesses the impact of the RTA year after year. In this paper, we propose a variable designed to assess the impact of the RTA after a given period of membership. The variable we propose is based on the count of the number of years each member has participated. We thus combine the expansion dimension of the RTA (the evolution of the membership over time) and the cumulative cooperation experience of the members over time. 
For instance, let us consider the membership of the Central American Common Market (CACM): El Salvador, Guatemala, Honduras and Nicaragua created this RTA in 1960, and Costa Rica joined in 1962. Let us call YP(i,t) the number of years of participation of member country $i$ in the RTA at date $t$. Table 2 illustrates CACM member participation in 1988, 1990 and 1992.

Table 2: Number of years CACM members have participated

\begin{tabular}{|c|c|c|c|c|}
\hline & \multicolumn{3}{|c|}{ Years of participation: $Y P(i, t)$} & \multirow[b]{2}{*}{ Year: } \\
\hline & 1988 & 1990 & 1992 & \\
\hline El Salvador & 29 & 31 & 33 & \\
\hline Guatemala & 29 & 31 & 33 & \\
\hline Honduras & 29 & 31 & 33 & \\
\hline Nicaragua & 29 & 31 & 33 & \\
\hline Costa Rica & 27 & 29 & 31 & \\
\hline Member: $i$ & & & & \\
\hline
\end{tabular}

To compute the RTA variable, we distinguish between the exporter (country i) and the importer (country $j$ ). Each RTA is thus characterized by three variables representing respectively export flows from a member to a non-member $\left(V_{R T A-R O W}\right)$, export flows from a non-member to a member ( $\left.V_{R O W-R T A}\right)$, and export flows between members $\left(V_{R T A-R T A}\right)$. These variables depend on $i, j$ and $t$ :

$V_{\text {RTA-ROW }}(i, j, t)=Y P(i, t)$ if $i$ belongs to RTA and $j$ does not, 0 otherwise

$V_{R O W-R T A}(i, j, t)=Y P(j, t)$ if $j$ belongs to RTA and i does not, 0 otherwise

$V_{\text {RTA-ROW }}(i, j, t)=\operatorname{Min}\{Y P(i, t), Y P(j, t)\}$ if $i$ and $j$ belong to RTA, 0 otherwise

To take account of anticipation effects from the beginning of the negotiation of the RTA to the end of the first year of existence, we can start the analysis a certain number of years ahead of the date of entry into force. We arbitrarily choose ten years. This is sufficient to capture any anticipation effect following Freund and McLaren (1999) who estimate this period to be approximately 12 years. Under this hypothesis, the RTA variables become:

$\tilde{V}_{R T A-R O W}(i, j, t)=Y P(i, t)+10$ if $i$ belongs to RTA and $j$ does not, 0 otherwise

$\tilde{V}_{R O W-R T A}(i, j, t)=Y P(j, t)+10$ if $j$ belongs to RTA and $i$ does not, 0 otherwise

$\tilde{V}_{R T A-R O W}(i, j, t)=\operatorname{Min}\{Y P(i, t), Y P(j, t)\}+10$ if $i$ and $j$ belong to RTA, 0 otherwise (6)

These measures help to take into account the variation in membership and the cumulative 
cooperation effect over time of the RTA.

\subsection{The two-step estimation approach}

The gravity equation is the most used tool to analyze the trade impact of RTAs. However, regardless of any theoretical base, most of the empirical papers addressing RTAs' trade impact impose a linear relationship between RTAs and trade flows through the inclusion of dummy variables. A non-parametric approach would let the data impose the relevant structure to the RTA-Trade flows relation and this paper proposes an estimation approach in this vein. We proceed in two steps.

\subsubsection{First step: the gravity equation estimation}

First, we have to estimate a simple gravity model not including any RTA measures. In the empirical trade literature, many recent papers have revisited the formulation of the gravity equation by proposing different set of dummy variables to be included to control for the price and the remoteness term. Among these papers, we can mention Baier and Bergstrand (2002), Anderson and van Wincoop (2003), Martinez-Zarzoso and NowakLehmann (2003), and Cheng and Wall (2005). The recent paper by Baldwin and Taglioni (2006) summarizes this debate and describes the common errors made in this empirical literature. Basically, three current errors are made: the inadequate deflation of trade flows by CPI, a misleading bilateral trade average (taking the log of average bilateral trade instead of the average of the log of bilateral trade), and the omission or the incorrect inclusion of the multi-lateral resistance term. All these errors lead to biased estimates of the trade impact of any trade policy.

Baldwin and Taglioni propose some improvements of the empirical estimation of gravity equations: use unidirectional trade flows and include country-pair and time dummy variables, or country-time dummy variables. Both options correct for the inadequate deflation of the trade flows, but correct for omission of the multi-lateral resistance only partially. Baldwin and Taglioni's preferred specification is to include both country-pair and country-time dummy. However, they acknowledge that since most of the trade policies examined by trade economists are country-pair specific, this approach alters the estimation of the trade impact of these policies.

Against this backdrop, we propose two specifications incorporating most of the suggestions of Baldwin and Taglioni. The first specification includes country-pair and time dummies, the second includes country-time dummies and some bilateral geographical variables to partially control for the omitted country-pair dummies:

$$
\begin{aligned}
& \operatorname{LnX} X_{i j t}=\alpha_{1} \operatorname{LnGDP}_{i t}+\alpha_{2} \operatorname{LnGDP_{jt}}+\beta_{1} \operatorname{LnPOP}_{i t}+\beta_{2} \operatorname{LnPOP}_{j t} \\
& +\theta \operatorname{LnRER}_{i j t}+\gamma t+\delta_{0}+F E_{i j}+F E_{t}+\varepsilon_{i j t}
\end{aligned}
$$




$$
\begin{aligned}
& \operatorname{LnX}_{i j t}=\alpha_{0} \text { LnDist }_{i j}+\alpha_{1} \operatorname{LnGDP}_{i t}+\alpha_{2} \operatorname{LnGDP}_{j t}+\beta_{1} \operatorname{LnPOP}_{i t}+\beta_{2} \operatorname{LnPOP}_{j t} \\
& +\theta \operatorname{LnRER}_{i j t}+\gamma t+\delta_{0}+F E_{i t}+\sum_{k} G e o_{i j}^{k}+\varepsilon_{i j t}
\end{aligned}
$$

where $X_{i j t}$ is country $i$ 's export to country $j$ at period $t$, Dist ${ }_{i j}$ is the distance between country $i$ and $j, G D P_{i t}$ is the GDP of country $i$ in year $t, P O P_{i t}$ is the population of country $i$ in year $t, R E R_{i j t}$ is a measure of the real exchange rate between country $i$ and $j$ in year $t, t$ is the time trend so that $\gamma$ measures the long term effect of time on trade flows, $\delta_{0}$ is an intercept common to all years and country-pairs, $F E_{i j}$ (with $F E_{i j} \neq F E_{j i}$ ) is the countrypair fixed effects, $F E_{i t}$ is the exporter-year fixed effects, $F E_{t}$ is year fixed effects, and $\mathrm{GeO}_{i j}{ }^{k}$ is a set of $k$ bilateral geographical variables. ${ }^{2}$ Following Rose (2003), we consider the following bilateral geographical variables: Border (sharing a common border), Colony (colonizer-colony relationship), Comcol (sharing a common colonizer), Comlang (sharing a common language), and Curcol (currently in a colony-colonizer relationship). $\varepsilon_{i j t}$ is the error term.

\subsubsection{Second step: the non-parametric estimation}

The estimated residuals of these two equations are extracted and used in the second step for the non-parametric part of the estimation.

Imagine a scatter plot depicting the estimated trade residuals $\left(\hat{\varepsilon}_{i j t}\right)$ against one of the three RTA variables described in the previous section $\left(\tilde{V}_{R T A-R O W}(i, j, t), \tilde{V}_{R O W-R T A}(i, j, t)\right.$, or $\left.\tilde{V}_{R T A-R T A}(i, j, t)\right)$. The point is to evaluate the nonparametric function $f($.$) underlining the variation of \hat{\varepsilon}_{i j t}$ in accordance with $\tilde{V}_{R T A-R O W}(i, j, t), \tilde{V}_{R O W-R T A}(i, j, t)$, or $\left.\tilde{V}_{R T A-R T A}(i, j, t)\right)$ by using a kernel estimator:

$$
\begin{aligned}
& E\left(\varepsilon_{i j t} \mid V_{\text {RTA-ROW }}(i, j, t)\right)=\hat{f}\left(V_{\text {RTA-ROW }}(i, j, t)\right) \\
& E\left(\varepsilon_{i j t} \mid V_{\text {ROW-RTA }}(i, j, t)\right)=\hat{f}\left(V_{\text {ROW-RTA }}(i, j, t)\right) \\
& E\left(\varepsilon_{i j t} \mid V_{\text {RTA-RTA }}(i, j, t)\right)=\hat{f}\left(V_{\text {RTA-RTA }}(i, j, t)\right)
\end{aligned}
$$

where:

\footnotetext{
${ }^{2}$ Our real exchange rate variable is inspired by Soloaga and Winters (2000):

$R E R_{i j t}=\left(e \times \Pi_{U S, t} / \Pi_{i, t}\right) \cdot\left(e \times \Pi_{U S, t} / \Pi_{j, t}\right)$ where $e$ is the value of 1 US $\$$ evaluated in the currency of country $i$ and $\prod$ is the GDP deflator.
} 


$$
\hat{f}(x)=\frac{\sum_{i=1}^{n} K\left(x_{i}\right) \cdot \hat{\varepsilon}_{i j t} / \gamma_{n}}{\sum_{i=1}^{n} K\left(x_{i}\right) / \gamma_{n}}
$$

where $n$ is the number of observations, $\gamma_{n}$ is an a-priori chosen sequence of positive numbers called the window width parameter and $K($.$) is an a-priori chosen real function$ called the kernel, and satisfying $\int|K(x)| d x<\infty$ and $\int K(x) d x=1$.

Bieriens (1994) analyses the asymptotic property of this estimator, and shows that it is asymptotically normal, that is:

$$
\sqrt{n}[\hat{f}(x)-f(x)] \rightarrow N(0, V(x))
$$

where $V(x)$ depends on the characteristics of the kernel function $K(x)$.

Bierens shows that the specific choice of the kernel function is not crucial: any Gaussian kernel is relevant. More important is the choice of the bandwidth that controls the trade-off between bias and variance of the estimated trade effects. Since the RTA variables are discrete variables (number of years of participation), we choose a bandwidth $\gamma_{n=1}$ so as to smooth trade effects over a one-year period. Bierens (1994) describes in detail how to use equation (13) to directly build the Confidence Interval of the estimated trade effects.

\section{Empirical Analysis}

In this section, we present and discuss the data used to evaluate the trade effect of the seven developing RTAs under consideration.

\subsection{Data and estimation issues}

Our database comes from Rose (2003) completed with data on export price index from IFS. We divided the export values by the export price indices to obtain export quantities. The final database is an unbalanced panel containing 56 exporter and 90 importer countries over the period 1960-1999 (see the list in Appendix 2). It contains no zero trade flow and only $8 \%$ of export values are missing. We thus use a simple regression model to estimate the gravity models (7) and (8). Since we are using fixed effects, the estimators are not biased because of the unbalancedness of the database; however, we use the Huber/White estimator of the variance to correct for the potential heteroscedasticity problem. 
The estimation results of the gravity equations are reported in Appendix 3. ${ }^{3}$ Specification 1 corresponds to equation (7) including country-pair and year fixed effects and Specification 2 corresponds to equation (8) including exporter-year fixed effects. In Appendix 3, a parameter with an upper index $a$ is significant at the $1 \%$ level, that with an upper index $b$ is significant at the $5 \%$ level and that with an upper index $c$ is significant at the $10 \%$ level.

The traditional gravity variables (distance, GDP and Population) depict the expected sign and magnitude in the two specifications. The estimated coefficients of the real exchange rate variable are negative, indicating a slight decreasing competitiveness among trading partners over the period 1960-1999 after controlling for the traditional gravity variables.

The time trend is not statistically significant in Specification 1. The bilateral geographical variables' coefficients are statistically significant with the expected signs and magnitudes.

In the second step, we extracted the estimated trade residuals from equations (7) and (8), and run a kernel regression as described in Section 2.2. We then used equation (13) to build the confidence interval as follows: for each grid point, we consider the standard deviation $(\sigma)$ from equation (13) and use it to compute the $95 \%$ confidence interval of the trade effects defined as $\pm 1.96 \times \sigma$, where $\sigma=\sqrt{1 /(12 n)}, n$ being the total number of years of existence of a given RTA and 1/12 being the variance of the uniform distribution. ${ }^{4}$ The results are presented graphically in Appendix 4.

Following Baldwin and Taglioni (2006), we choose the specification including the exporter-year fixed effects as our preferred estimation and comment the results in the next section.

\subsection{The trade effect of some developing RTAs}

The ASEAN Free Trade Agreement (AFTA) was created in 1992 by six members of the Association of South East Asian Nations (Brunei Darussalam, Indonesia, Malaysia, Philippines, Singapore and Thailand), four other members joined subsequently (Vietnam in 1995, Laos and Myanmar in 1997, Cambodia in 1999). The AFTA members included in the estimation as exporter and importer are Indonesia, Malaysia, Philippines Singapore and Thailand, the remaining members being included only as importers. Figure 2 of

\footnotetext{
${ }^{3}$ We do not report exporter-year, country-pair and year fixed effects to save space. Note also that since equation (8) introduces exporter-years fixed effects, the variables with the index it are absorbed in this specification.
}

${ }^{4}$ See Bierens (1994) for a full explanation of this process. 
Appendix 4 plots the estimated trade residuals against the AFTA membership evolution over time: the top panel focuses on intra-AFTA exports $\left(X_{\text {AFTA-AFTA }}\right.$ ), the middle panel focuses on AFTA's imports flows from the ROW ( $X_{\text {ROW-AFTA }}$ ) and the bottom panel focuses on AFTA's exports to the ROW ( $X_{\text {AFTA-ROW }}$ ). The dashed lines represent the estimated 95\% confidence interval. These graphs clearly show an anticipation effect of AFTA members which started increasing their intra-trade five years before the official year of joining this RTA. In addition, the trade effect of AFTA seems to be globally positive over the estimation period since its effect on intra-AFTA exports and imports from the ROW are estimated to be positive and increasing. However, its impact on export flows remained neutral.

The Central American Common Market (CACM), was created in 1960 by El Salvador, Guatemala, Honduras, Nicaragua. Costa Rica joined in 1962. It is notified at the WTO as a Customs Union. Except for El Salvador included as importer only, all the CACM members are both exporter and importer in the database. Figure 3 of Appendix 4 plots the estimated trade residuals against the number of years of each CACM member's participation. The RTA's impact on intra-CACM exports are estimated to be negative during the first years of its existence, and then it became positive and increasing over time. The tensions between El Salvador and Honduras in the late sixties may explain this initial negative impact. ${ }^{5}$ The RTA's impact on its members' exports to and imports from the ROW are estimated to be negative and sometimes decreasing, a result suggesting an overall ambiguous trade effect of the CACM.

The Andean Community (CAN) is a preferential agreement signed in 1988 by Bolivia, Colombia, Ecuador, Peru and Venezuela. Except for Venezuela included as importer only, all the other CAN members are both exporter and importer in the database used for the estimations. Figure 4 of Appendix 4 plots the estimated trade residuals against the number of years of CAN members' participation. Intra-CAN exports seem to have started increasing three years before the official date of entry into force of this RTA. It remained positive and increasing over the estimation period. However, the RTA's effects on imports from and exports to the ROW are estimated to be negative or neutral.

The Economic Community of West African States (ECOWAS) is a political association created in 1975 by fifteen members (Mauritania withdrew in 1999): Benin, Burkina Faso, Cape Verde, Côte d'Ivoire, Gambia, Ghana, Guinea, Guinea-Bissau, Liberia, Mali, Niger, Nigeria, Senegal, Sierra Leone, Togo. Except for Burkina Faso, Côte d'Ivoire, Liberia, Nigeria, Senegal and Togo that are included as exporter and

\footnotetext{
${ }^{5}$ In fact, the CACM collapsed in 1969 after a five-day war that had been known as the "soccer war" between El Salvador and Honduras. After this episode, the partners tried to slowly re-establish their collaboration. This may explain the abnormal trade effects observed. We may also notice that in Figure 4 of appendix 5, the CACM trade flows are limited to two years before the official date of entry into force (1962 for Costa Rica) because the database used is limited on the period 1960-1999.
} 
importer, the remaining members are included in the database as importers only. Figure 5 in Appendix 4 plots the estimated trade residuals against the number of years these countries have participated in the ECOWAS. These graphs indicate a slight anticipation effect of ECOWAS members five years before the official date of its creation. The RTA's impact on intra-ECOWAS trade flows is estimated to be positive and increasing over the estimation period, while its impact on its members exports to the ROW is negative and decreasing over time. During the first ten years of the existence of the RTA, its impact on its members imports from the ROW was estimated to be positive, but this result was reversed after. The overall trade impact of the ECOWAS is thus ambiguous.

The Southern Common Market (MERCOSUR) was established in 1991 between Argentina, Brazil, Paraguay and Uruguay. Except for Uruguay included as importer only, the other MECOSUR members are included as exporter and importer in the database. Figure 6 of Appendix 4 plots the estimated export volume residuals against the number of years of member participation. These graphs indicate that MERCOSUR members were very involved in intra-trade five years before the official date of implementation of this RTA. The RTA's impact on its members intra-trade is estimated to be positive and increasing over time, while its impact on their imports from the ROW is negative. The RTA appears to have had no impact on its members exports to the ROW.

The South African Development Community (SADC) is a political association created in 1992 by fourteen members: Angola, Botswana, Democratic Republic of Congo, Lesotho, Malawi, Mauritius, Mozambique, Namibia, Seychelles, South Africa, Swaziland, Tanzania, Zambia, Zimbabwe. Except for Malawi, Mauritius, Seychelles, South Africa, Zambia and Zimbabwe included as importer and exporter in the database, the other SADC members are included as importers only. Figure 7 in Appendix 4 plots the estimated trade residuals against the number of years of SADC member participation. Figure 7 reveals an anticipation effect of SADC members depicted by a continuous increase in the intra-SADC trade flows five years before the official implementation date. The RTA's impact on its members' intra-trade is estimated to be positive and increasing. However, its impact on their exports to or imports from the ROW are estimated to be slightly negative.

The last RTA analyzed is the South Asian Preferential Trade Agreement (SAPTA) comprising Bangladesh, Bhutan, India, Maldives, Nepal, Pakistan, and SriLanka. The treaty creating the SAPTA was signed on April 1993, and it enters into force in December 1995. Except for India, Pakistan and Sri-Lanka included as importers and exporters, the other members are included only as importers in the database. Figure 8 of Appendix 4 plots the estimated trade residuals against the number of years of SAPTA members' participation. The RTA's impacts on its members intra-trade and imports from the ROW are estimated to be negative, while its impact on the members exports to the ROW is estimated to be neutral. The recurrent tensions between India and Pakistan over the estimation period may explain the negative impact on intra-SAPTA trade flows.

\section{Conclusion}


This paper proposes two contributions to the evaluation of RTAs' trade impacts. First, we use an RTA variable that takes into account the number of years each member has participated instead of the usual RTA dummy variable. Second, we combine traditional gravity regressions with non-parametric estimation techniques so as to capture the nonmonotonic trade effects while imposing minimal structure on the model.

We focus on a panel of seven developing RTAs covering Africa, Asia and Latin America. Except for SAPTA, all these RTAs appear to have had a positive impact on their members' intra-trade over the estimation period (1960-1999). AFTA seems to be the most successful of these RTAs with an estimated positive impact on its members imports from the ROW (hence no trade diversion), but its impact on their exports to the ROW is rather limited. During its first ten years of existence, ECOWAS has had a positive impact on its members imports from the ROW (hence no trade diversion), but this positive impact vanished over time. SAPTA's negative impact on its members' intra-trade is probably an implicit effect of the India-Pakistan tensions over the estimation period.

This work is based on the up-to-date formulation of the gravity model and the proposed semi-parametric estimation approach can be easily implemented to rigorously assess the trade impact of developing RTAs. It could be improved and used as a key diagnostic tool to evaluate the trade impact of the various RTAs signed between many World Bank clients. 


\section{References}

Anderson, J.E., van Wincoop, E., 2003. Gravity with Gravitas: a Solution to the Border Puzzle. American Economic Review, 93:170-192.

Baier, S.L., Bergstrand, J.H, 2002. On the Endogeneity of International Trade Flows and Free Trade Agreements. American Economic Association Annual Meeting.

Bierens, H.J., 1994. Topics in Advanced Econometrics. Cambridge University Press.

Baldwin, R., Taglioni, D., 2006. Gravity for Dummies and Dummies for Gravity Equations. NBER working papers No. 12516.

Carrere, C., 2006. Revisiting the Effects of Regional Trade agreements on Trade Flows with Proper Specification of the Gravity Model. European economic Review, 50:223247.

Cernat, L., 2001. Assessing Regional trade Arrangements: Are South-South RTAs More Trade Diverting? Global economy Quarterly, 2(3):235-59.

Cheng, I.H., Wall, H.J., 2005. Controlling for Heterogeneity in Gravity Model of Trade and Integration. The Federal Reserve Bank of St. Louis Review, 87(1):49-63.

Dee, ph., Gali, J., 2003. The Trade and Investment Effect of Preferential Trade Arrangements. NBER Working Paper No. 10160.

Elliot, R., Ikemoto, K., 2004. AFTA and the Asian Crisis: Help or Hindrance to the ASEAN Intraregional Trade? Asian Economic Journal, 18(1):1-10.

Freund, C.L., McLaren, J., 1999. On the dynamics of Trade Diversion: Evidence from Four Trade Blocs. International Finance Discussion Paper no. 637.

Gosh, s., Yamarik, S., 2004. Are Regional Trading Arrangements Trade Creating? An application of Extreme Extreme Bounds Annalysis. Journal of International Economics, 63(2):369-395.

Krueger, A., 1999. Trade Creation and Trade Diversion under NAFTA. NBER Working Paper No. 7429.

Martinez-Zarsoso, I., Nowak-Lehman, F., 2003. Augmented Gravity Model: An Empirical Application to MERCOSUR-EU Trade Flows. Journal of applied economics, 6(2):291-316.

Rose, A., 2003. Does the WTO Make Trade More Stable? NBER Working Paper No. 10207.

Soloaga, I., Winters, A.L., 2000. Regionalism in the Nineties: What Effect on Trade? North American Journal of Economics and Finance, 12(1):1-29. 


\section{Appendix}

Appendix 1: A Panel of Developing RTAs

\begin{tabular}{|l|l|l|l|}
\hline Agreement & Full name & Membership evolution & Type \\
\hline ECOWAS & Economic & 1975: Benin & Political \\
\hline & Community & 1975: Burkina Faso & Association \\
\hline & Of West Africa & 1975: Cape Verde & \\
\hline & & 1975: Côte d'Ivoire & \\
\hline & & 1975: Gambia & \\
\hline & & $1975:$ Ghana & \\
\hline & & $1975:$ Guinea & \\
\hline & & $1975:$ Guinea Bissau & \\
\hline & & $1975:$ Liberia & \\
\hline & & $1975:$ Mali & \\
\hline & & $1975:$ Niger & \\
\hline & & $1975:$ Nigeria & \\
\hline & & $1975:$ Senegal & \\
\hline & & $1975:$ Sierra Leone & \\
\hline & & $1975:$ Togo & \\
\hline
\end{tabular}

\begin{tabular}{|l|l|l|l|}
\hline Agreement & Full name & Membership evolution & Type \\
\hline SADC & South African & 1992: Angola & Political \\
\hline & Development & 1992: Botswana & Association \\
\hline & Community & 1992: DR Congo & \\
\hline & & 1992: Lesotho & \\
\hline & & 1992: Malawi & \\
\hline & & 1992: Mauritius & \\
\hline & & 1992: Mozambique & \\
\hline & & 1992: Namibia & \\
\hline & & 1992: Seychelles & \\
\hline & & $1992:$ South-Africa & \\
\hline & & $1992:$ Swaziland & \\
\hline & & $1992:$ Tanzania & \\
\hline & & $1992:$ Zambia & \\
\hline & & & \\
\hline & & & \\
\hline & & & \\
\hline & & &
\end{tabular}

\begin{tabular}{|l|l|l|l|}
\hline Agreement & Full name & Membership evolution & Type \\
\hline CAN & Andean & 1988: Bolivia & Preferential \\
\hline & Community & 1988: Columbia & Arrangement \\
\hline & & 1988: Ecuador & \\
\hline & & 1988: Peru & \\
\hline & & 1988: Venezuela & \\
\hline
\end{tabular}




\begin{tabular}{|l|l|l|l|}
\hline Agreement & Full name & Membership evolution & Type \\
\hline CACM & Central & 1960: El Salvador & Customs \\
\hline & American & 1960: Guatemala & Union \\
\hline & Common & 1960: Honduras & \\
\hline & Market & 1960: Nicaragua & \\
\hline & & 1962: Costa Rica & \\
\hline
\end{tabular}

\begin{tabular}{|l|l|l|l|}
\hline Agreement & Full name & Membership evolution & Type \\
\hline MERCOSUR & Southern & 1991: Argentina & Customs \\
\hline & Common & 1991: Brazil & Union \\
\hline & market & 1991: Paraguay & \\
\hline & & 1991: Uruguay & \\
\hline
\end{tabular}

\begin{tabular}{|l|l|l|l|}
\hline Agreement & Full name & Membership evolution & Type \\
\hline AFTA & ASEAN & 1992: Brunei Darussalam & Political \\
\hline & Free Trade & 1992: Indonesia & Association \\
\hline & Agreement & 1992: Malaysia & \\
\hline & & 1992: Philippines & \\
\hline & & 1992: Singapore & \\
\hline & & 1992: Thailand & \\
\hline & & 1995: Vietnam & \\
\hline & & 1997: Laos & \\
\hline & & 1997: Myanmar & \\
\hline & & 1997: Cambodia & \\
\hline
\end{tabular}

\begin{tabular}{|l|l|l|l|}
\hline Agreement & Full name & Membership evolution & Type \\
\hline SAPTA & South Asia & 1995: Bangladesh & Preferential \\
\hline & Preferential & 1995: Bhutan & Agreement \\
\hline & Trade & 1995: India & \\
\hline & Agreement & 1995: Maldives & \\
\hline & & 1995: Nepal & \\
\hline & & 1995: Pakistan & \\
\hline & & 1995: Sri Lanka & \\
\hline
\end{tabular}




\section{Appendix 2: Exporter and importer countries}

\begin{tabular}{|c|c|c|c|c|c|c|c|}
\hline Code & Country & Exporter & Importer & Code & Country & Exporter & Importer \\
\hline 111 & United States & yes & yes & 522 & Cambodia & no & yes \\
\hline 112 & United Kingdom & yes & yes & 524 & Sri Lanka & yes & yes \\
\hline 122 & Austria & no & yes & 534 & India & yes & yes \\
\hline 124 & Belgium & yes & yes & 536 & Indonesia & yes & yes \\
\hline 128 & Denmark & yes & yes & 542 & Republic of Korea & yes & yes \\
\hline 132 & France & yes & yes & 544 & Lao People's Dem Rp & no & yes \\
\hline 134 & Germany & yes & yes & 548 & Malaysia & yes & yes \\
\hline 136 & Italy & yes & yes & 556 & Maldives & no & yes \\
\hline 137 & Luxembourg & no & yes & 558 & Nepal & no & yes \\
\hline 138 & Netherlands & yes & yes & 564 & Pakistan & yes & yes \\
\hline 142 & Norway & yes & yes & 566 & Philippines & yes & yes \\
\hline 144 & Sweden & yes & yes & 576 & Singapore & yes & yes \\
\hline 146 & Switzerland & yes & yes & 578 & Thailand & yes & yes \\
\hline 156 & Canada & yes & yes & 582 & Viet Nam & no & yes \\
\hline 158 & Japan & yes & yes & 614 & Angola & no & yes \\
\hline 172 & Finland & yes & yes & 616 & Botswana & no & yes \\
\hline 174 & Greece & yes & yes & 624 & Cape Verde & no & yes \\
\hline 176 & Iceland & yes & yes & 636 & Congo, Dem Rep of & no & yes \\
\hline 178 & Ireland & yes & yes & 638 & Benin & no & yes \\
\hline 181 & Malta & yes & yes & 648 & Gambia & no & yes \\
\hline 182 & Portugal & yes & yes & 652 & Ghana & no & yes \\
\hline 184 & Spain & yes & yes & 654 & Guinea-Bissau & no & yes \\
\hline 186 & Turkey & yes & yes & 656 & Guinea & no & yes \\
\hline 193 & Australia & yes & yes & 662 & Côte D'Ivoire & yes & yes \\
\hline 196 & New Zealand & yes & yes & 664 & Kenya & yes & yes \\
\hline 199 & South Africa & yes & yes & 666 & Lesotho & no & yes \\
\hline 213 & Argentina & yes & yes & 668 & Liberia & yes & yes \\
\hline 218 & Bolivia & yes & yes & 676 & Malawi & yes & yes \\
\hline 223 & Brazil & yes & yes & 678 & Mali & no & yes \\
\hline 233 & Colombia & yes & yes & 682 & Mauritania & no & yes \\
\hline 238 & Costa Rica & yes & yes & 684 & Mauritius & yes & yes \\
\hline 248 & Ecuador & yes & yes & 688 & Mozambique & no & yes \\
\hline 253 & El Salvador & no & yes & 692 & Niger & no & yes \\
\hline 258 & Guatemala & yes & yes & 694 & Nigeria & yes & yes \\
\hline 268 & Honduras & yes & yes & 698 & Zimbabwe & yes & yes \\
\hline 273 & Mexico & no & yes & 718 & Seychelles & yes & yes \\
\hline 278 & Nicaragua & yes & yes & 722 & Senegal & yes & yes \\
\hline 288 & Paraguay & yes & yes & 724 & Sierra Leone & no & yes \\
\hline 293 & Peru & yes & yes & 728 & Namibia & no & yes \\
\hline 298 & Uruguay & no & yes & 734 & Swaziland & no & yes \\
\hline 299 & Venezuela & no & yes & 738 & Tanzania & no & yes \\
\hline 513 & Bangladesh & yes & yes & 742 & Togo & yes & yes \\
\hline 514 & Bhutan & no & yes & 746 & Uganda & no & yes \\
\hline 516 & $\begin{array}{l}\text { Brunei } \\
\text { Darussalam }\end{array}$ & no & yes & 748 & Burkina Faso & yes & yes \\
\hline 518 & Myanmar & no & yes & 754 & Zambia & no & yes \\
\hline
\end{tabular}


Appendix 3: Gravity equation estimations

\begin{tabular}{|l|c|c|}
\cline { 2 - 3 } \multicolumn{1}{c|}{} & \multicolumn{2}{c|}{ Dependent variable: LnX $_{\mathrm{ijt}}$} \\
\cline { 2 - 3 } \multicolumn{1}{c|}{} & 1 & 2 \\
\hline LnDist $_{\mathrm{ij}}$ & & $-1.23^{\mathrm{a}}$ \\
LnGDP $_{i t}$ & $1.34^{\mathrm{a}}$ & \\
LnGDP $_{\mathrm{jt}}$ & $0.90^{\mathrm{a}}$ & $1.39^{\mathrm{a}}$ \\
LnPOP $_{\mathrm{it}}$ & $-0.06^{\mathrm{c}}$ & \\
LnPOP $_{\mathrm{jt}}$ & $-0.53^{\mathrm{a}}$ & $-0.57^{\mathrm{a}}$ \\
LnRER $_{\mathrm{ijt}}$ & $-0.002^{\mathrm{a}}$ & $-0.004^{\mathrm{a}}$ \\
$\mathrm{t}$ & -0.008 & \\
Border & & $0.16^{\mathrm{a}}$ \\
Colony & & $1.29^{\mathrm{a}}$ \\
Comcol & & $0.86^{\mathrm{a}}$ \\
Comlang & & $0.37^{\mathrm{a}}$ \\
Curcol & & $1.50^{\mathrm{a}}$ \\
Constant & $-23.44^{\mathrm{a}}$ & $1.96^{\mathrm{a}}$ \\
\hline $\mathrm{N}$ & 123,205 & 123,205 \\
\hline R & 0.45 & 0.29 \\
\hline P-value & 0.00 & 0.00 \\
\hline
\end{tabular}




\section{Appendix 4: Figures}

\section{Exporter-time fixed effects}

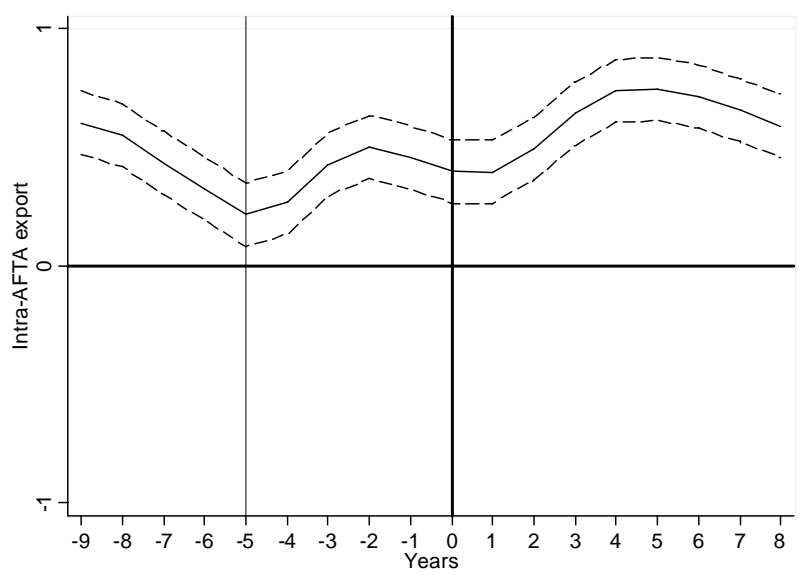

Exporter-time fixed effects

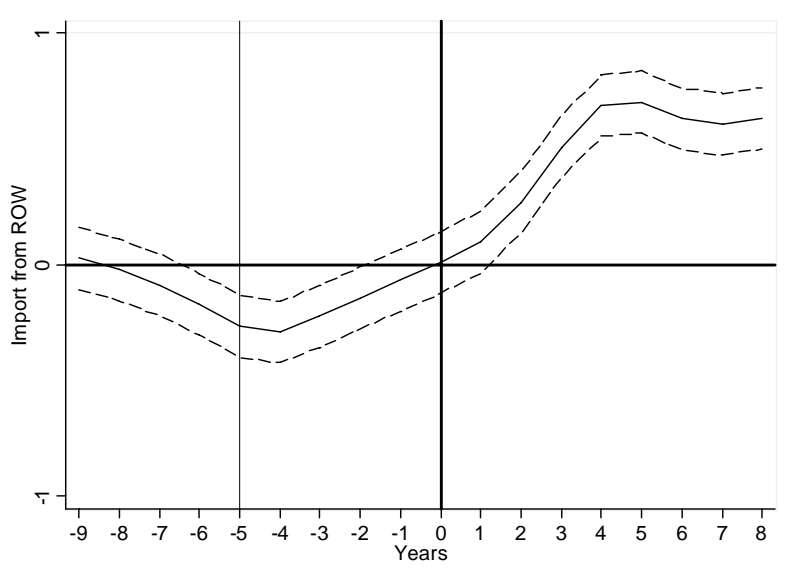

Exporter-time fixed effects

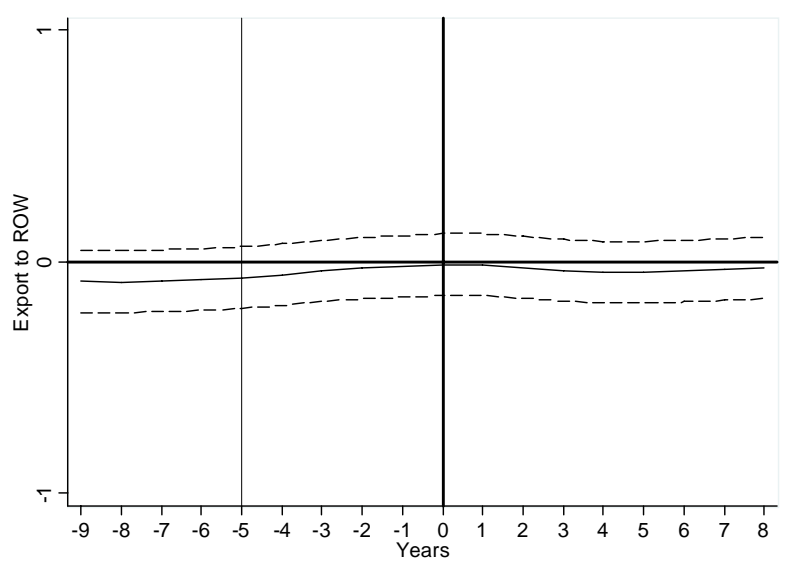

Country-pair and year fixed effects

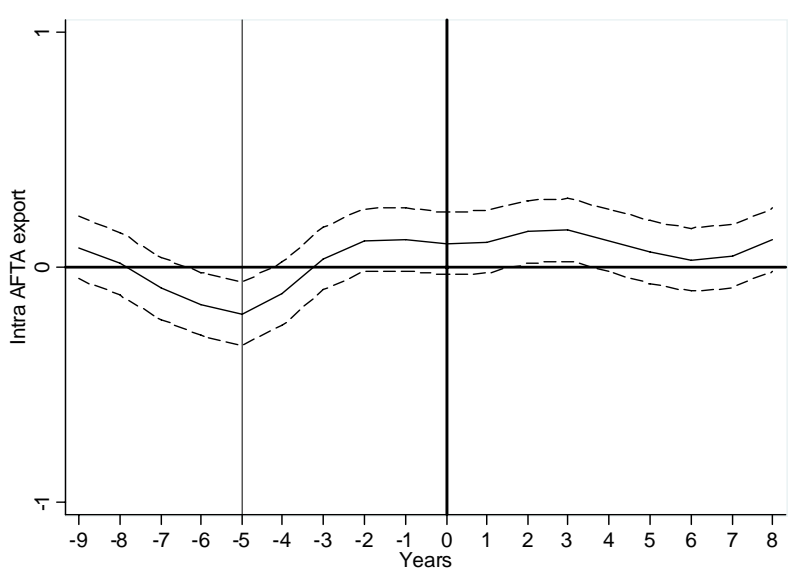

Country-pair and year fixed effects

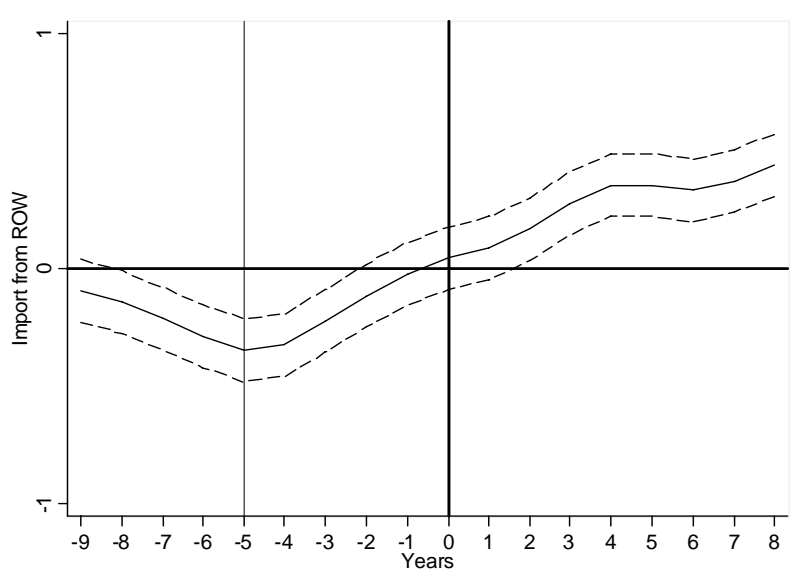

Country-pair and year fixed effects

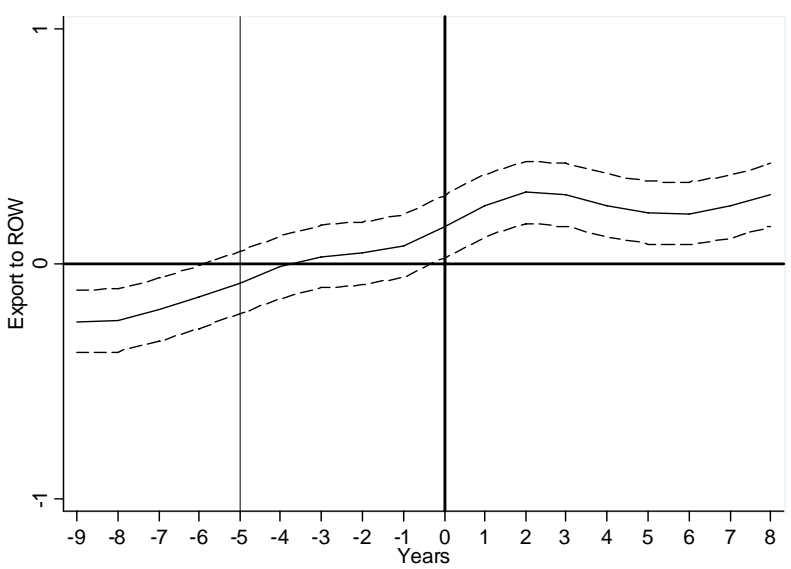

Figure 2: AFTA trade effects 
Exporter-time fixed effects

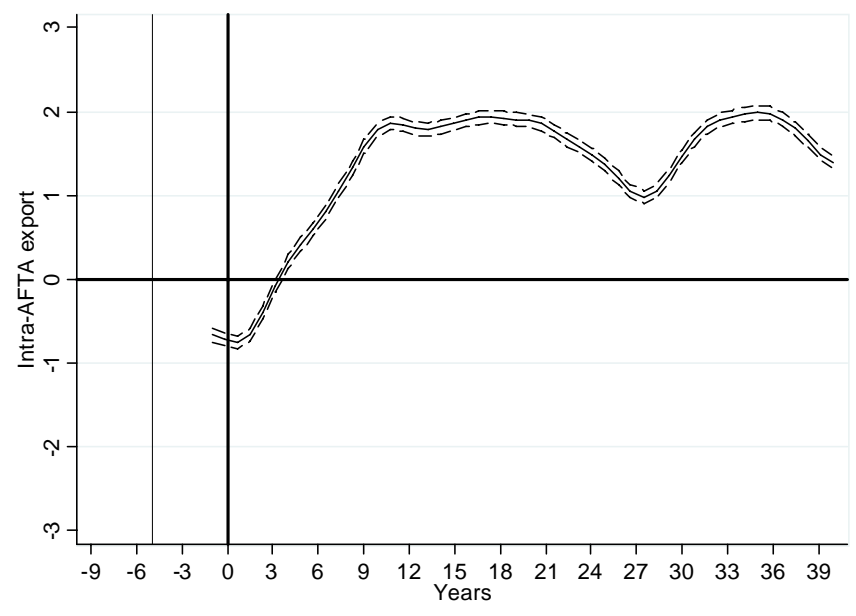

Exporter-time fixed effects

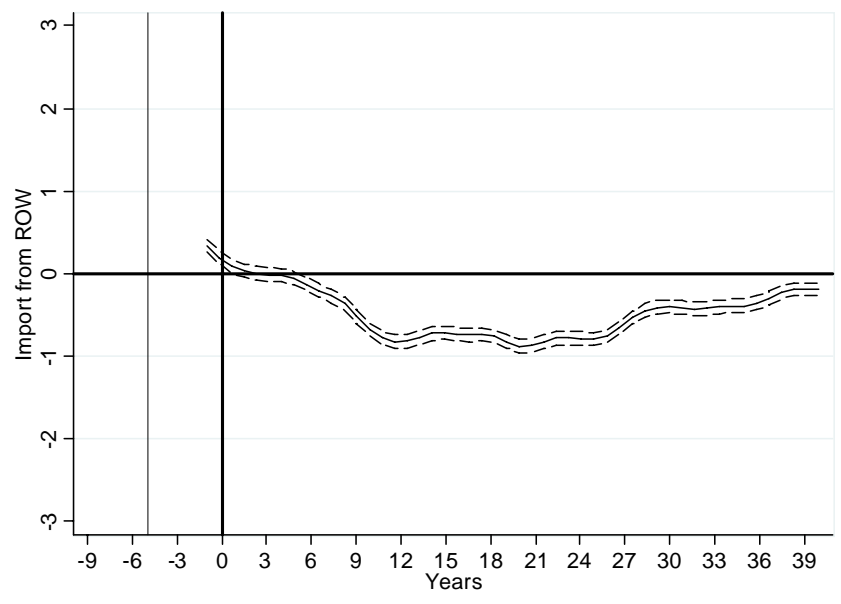

Exporter-time fixed effects

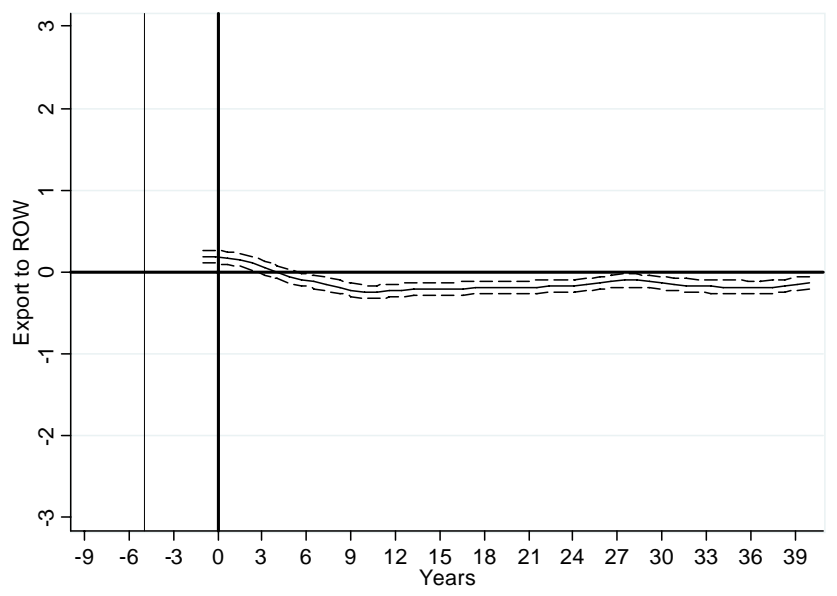

Country-pair and year fixed effects

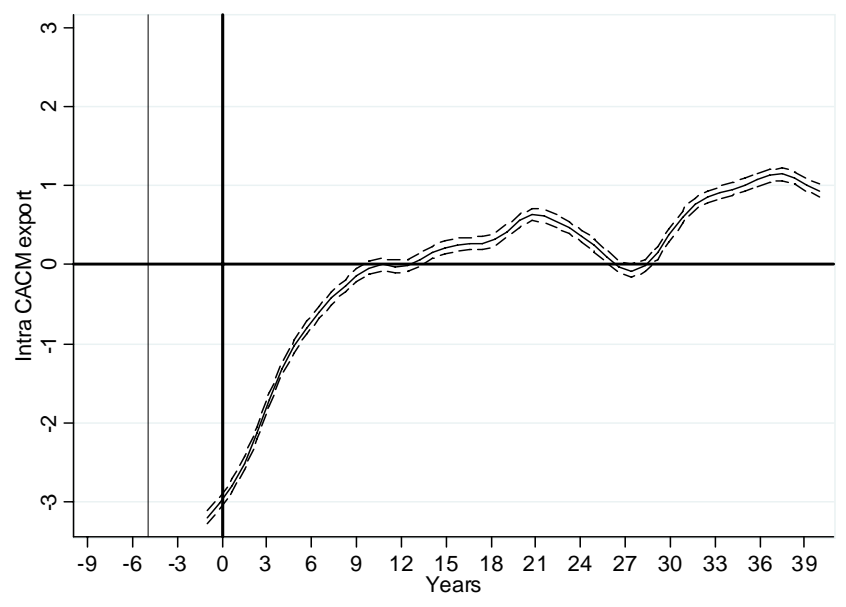

Country-pair and year fixed effects

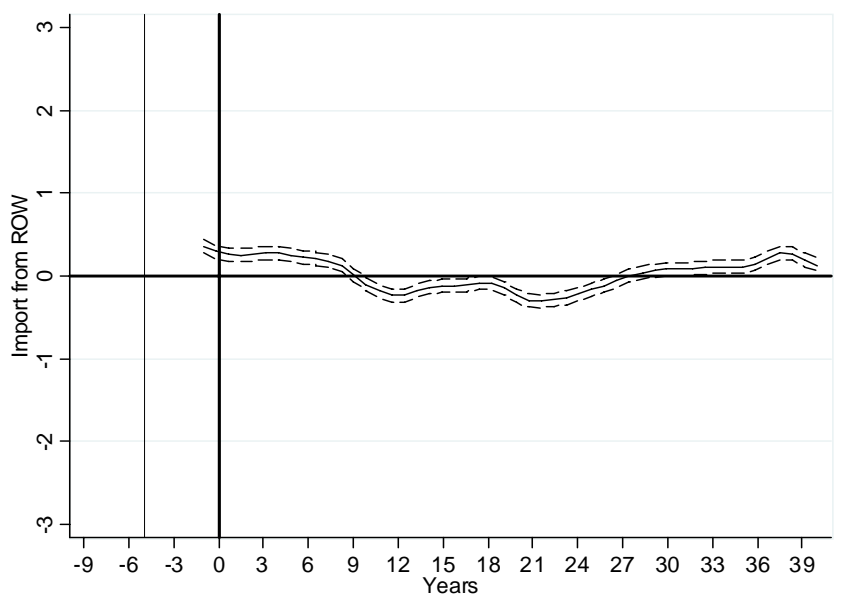

Country-pair and year fixed effects

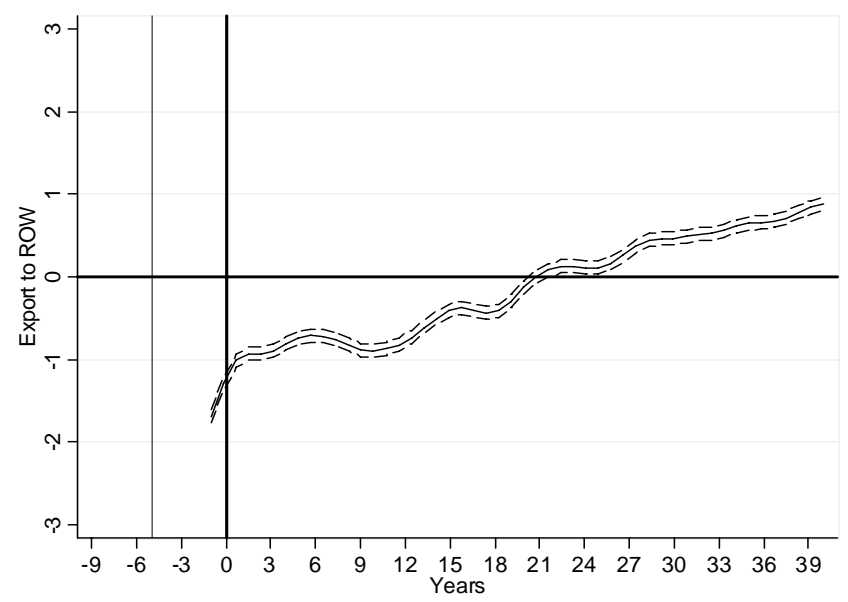

Figure 3: CACM trade effects 
Exporter-time fixed effects

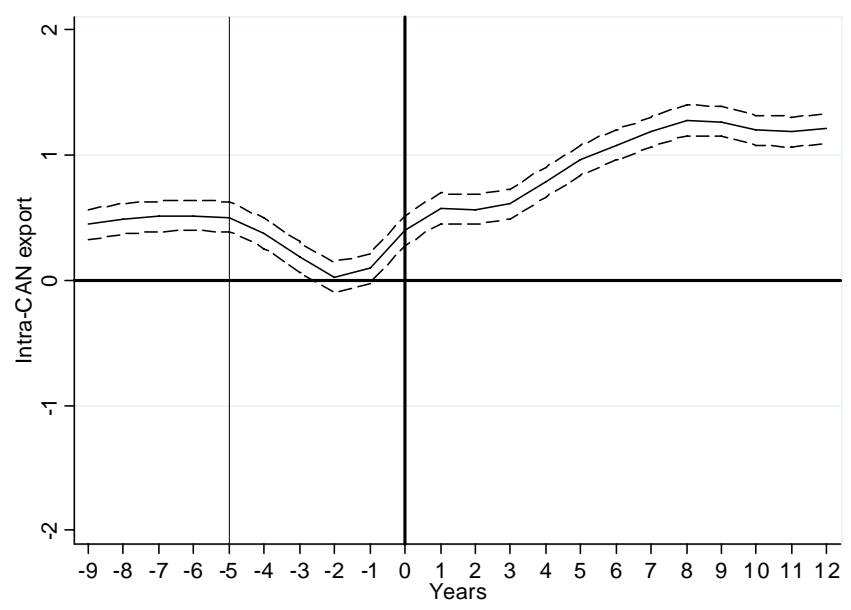

Exporter-time fixed effects

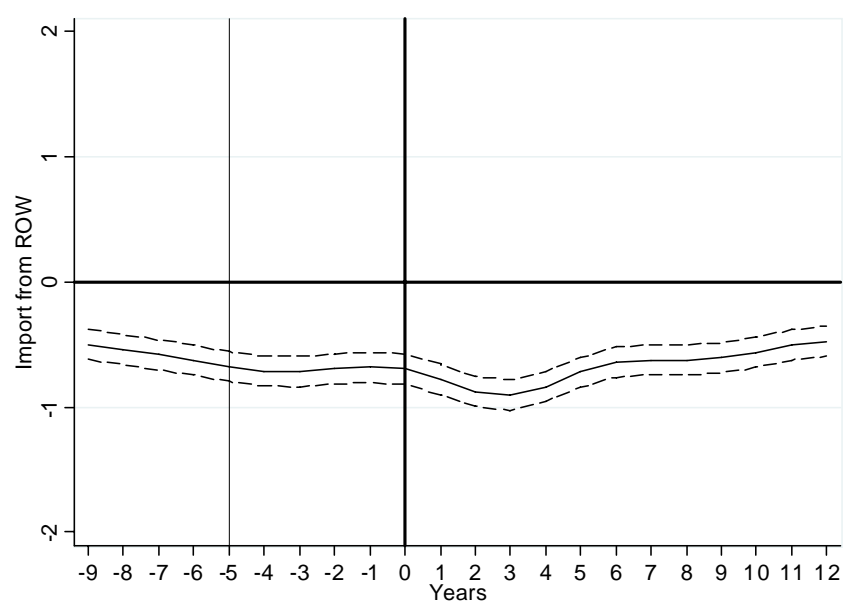

Exporter-time fixed effects

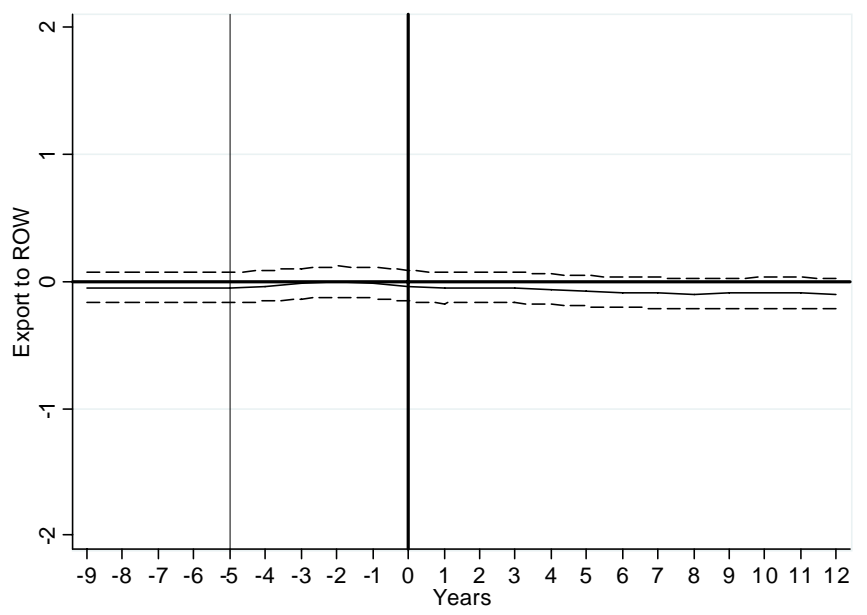

Country-pair and year fixed effects

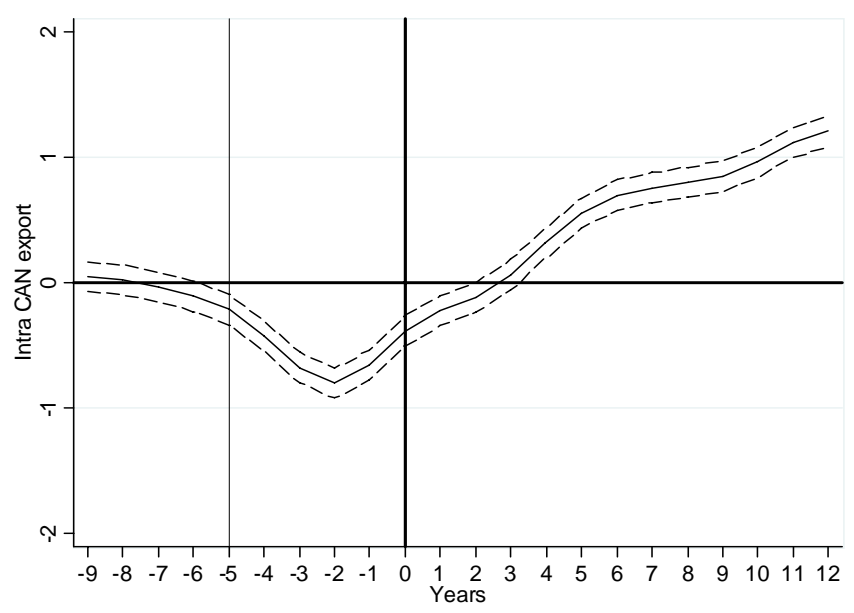

Country-pair and year fixed effects

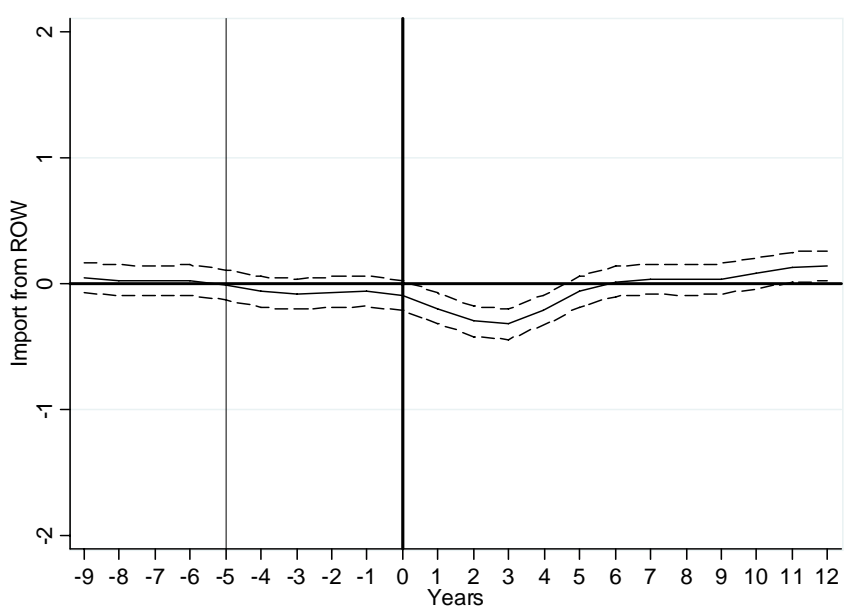

Country-pair and year fixed effects

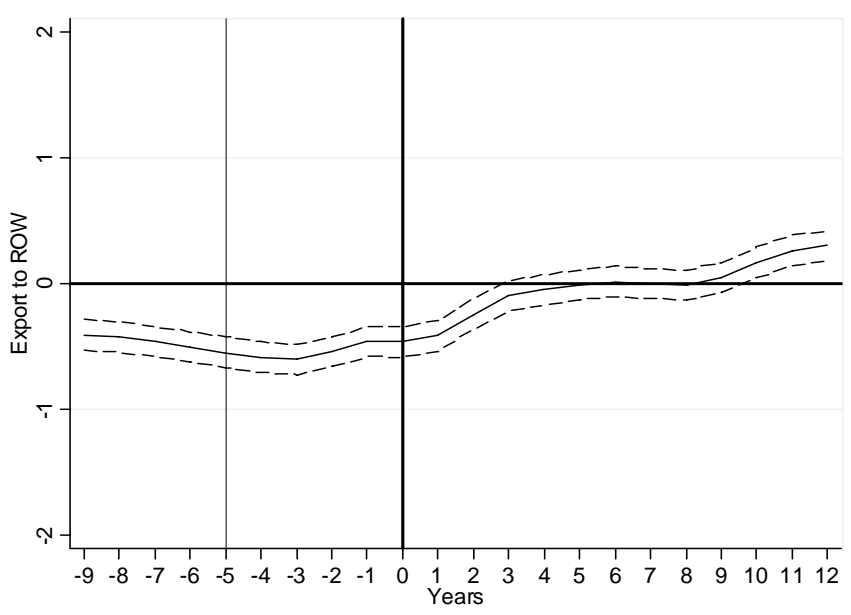

Figure 4: CAN trade effects 
Exporter-time fixed effects

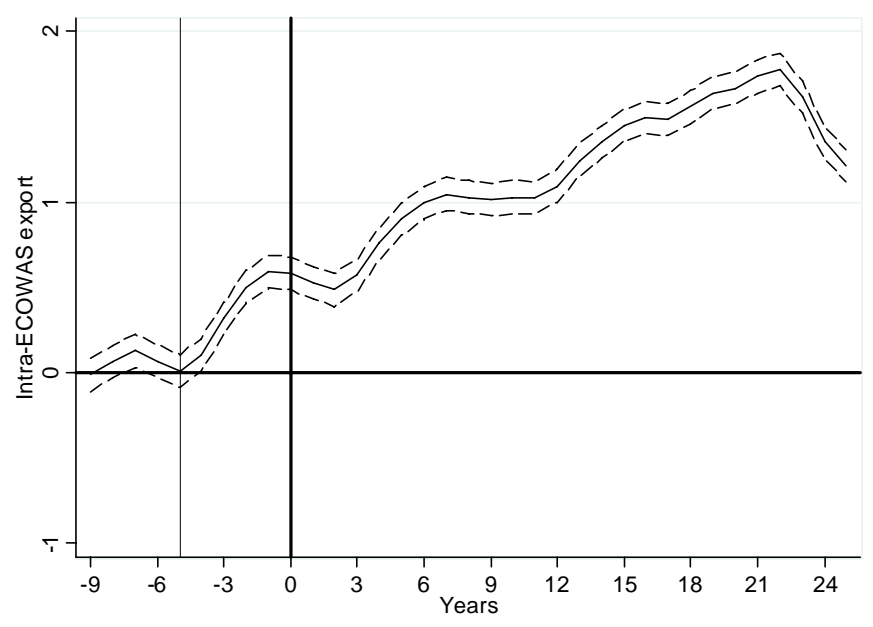

Exporter-time fixed effects

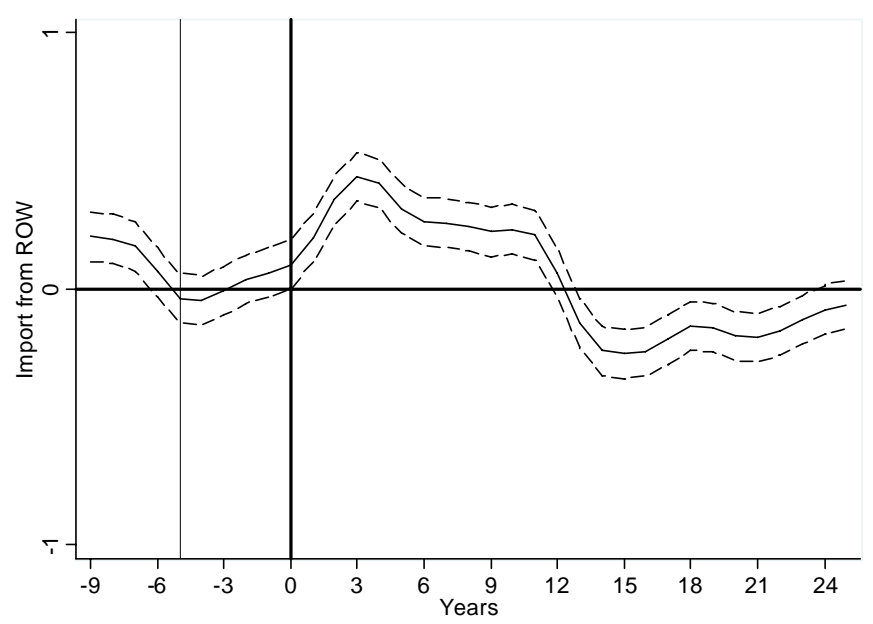

Exporter-time fixed effects

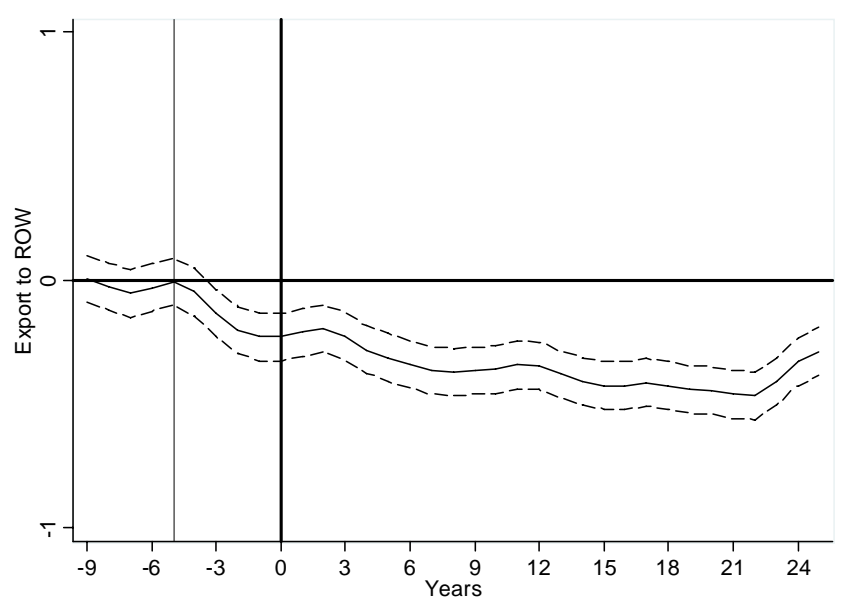

Country-pair and year fixed effects

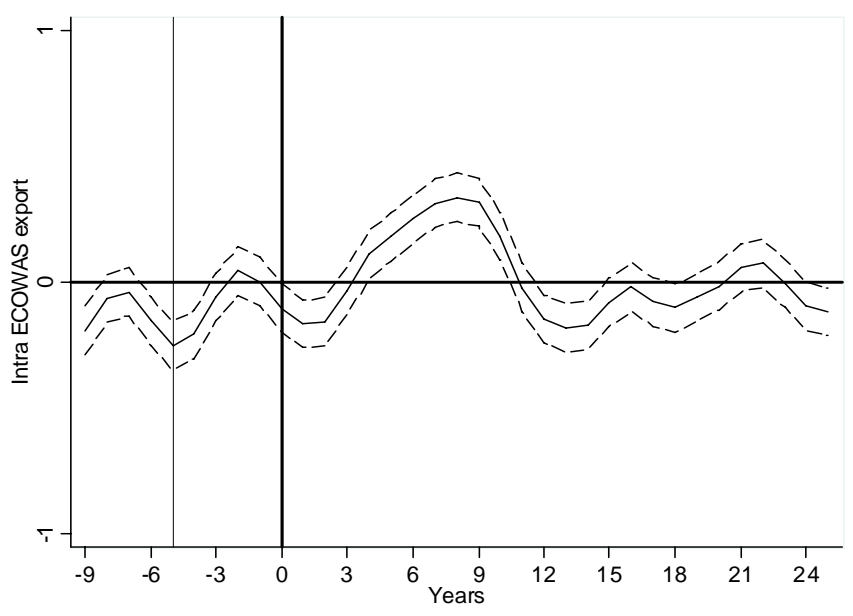

Country-pair and year fixed effects

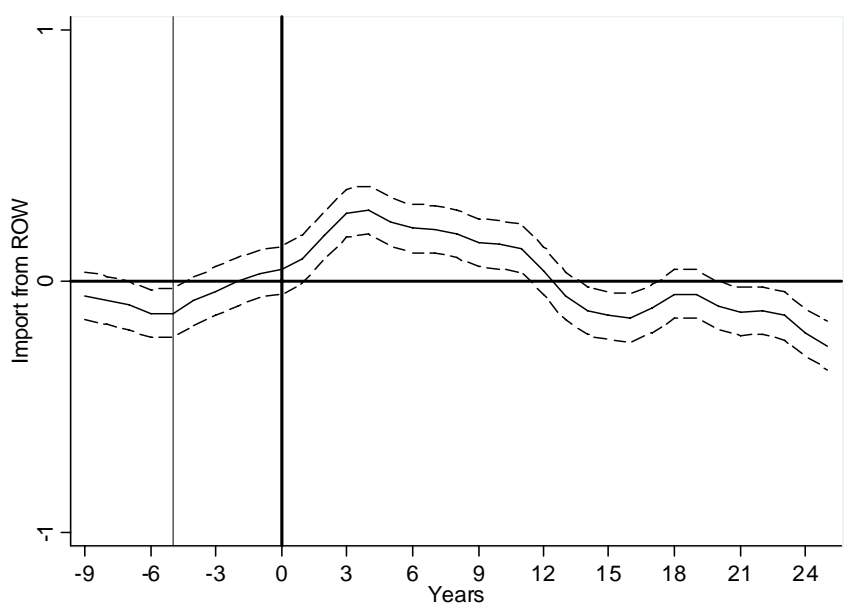

Country-pair and year fixed effects

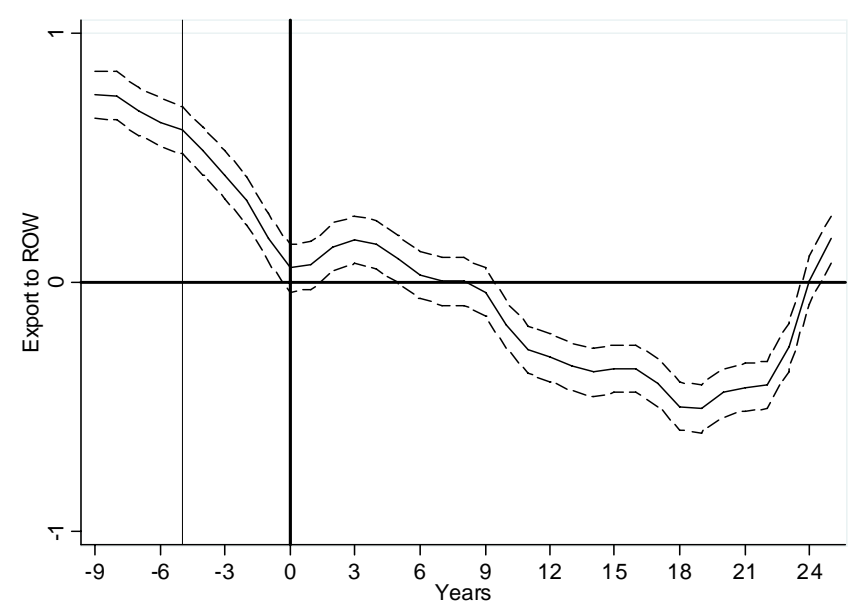

Figure 5: ECOWAS trade effects 
Exporter-time fixed effects

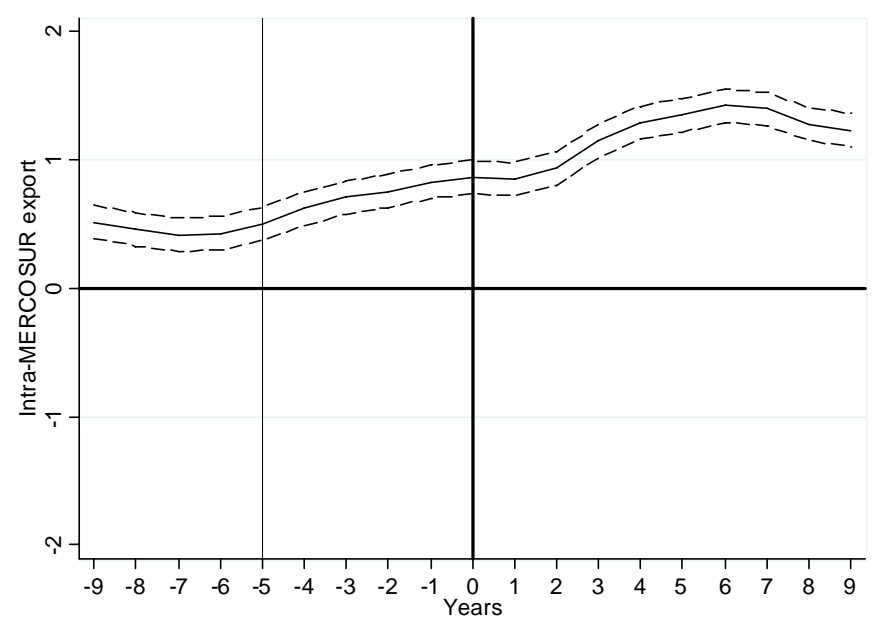

Exporter-time fixed effects

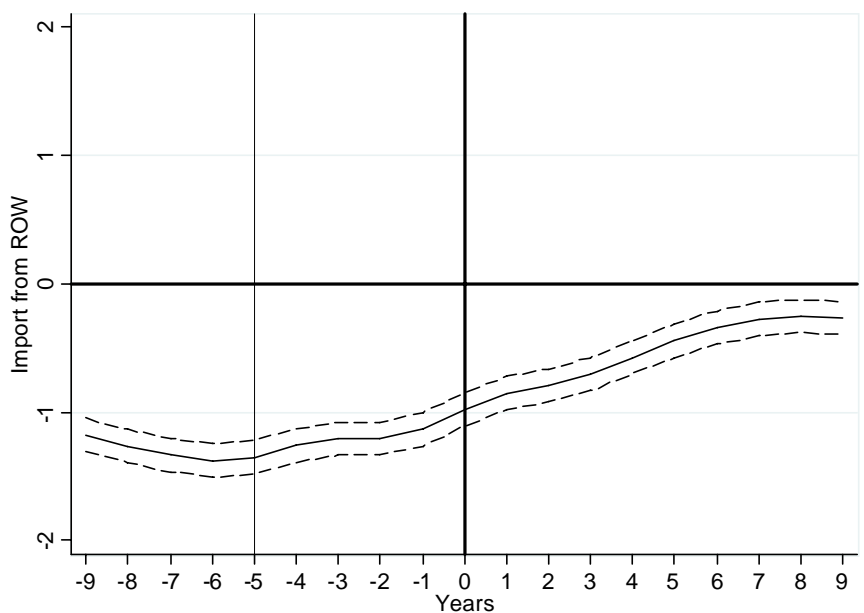

Exporter-time fixed effects

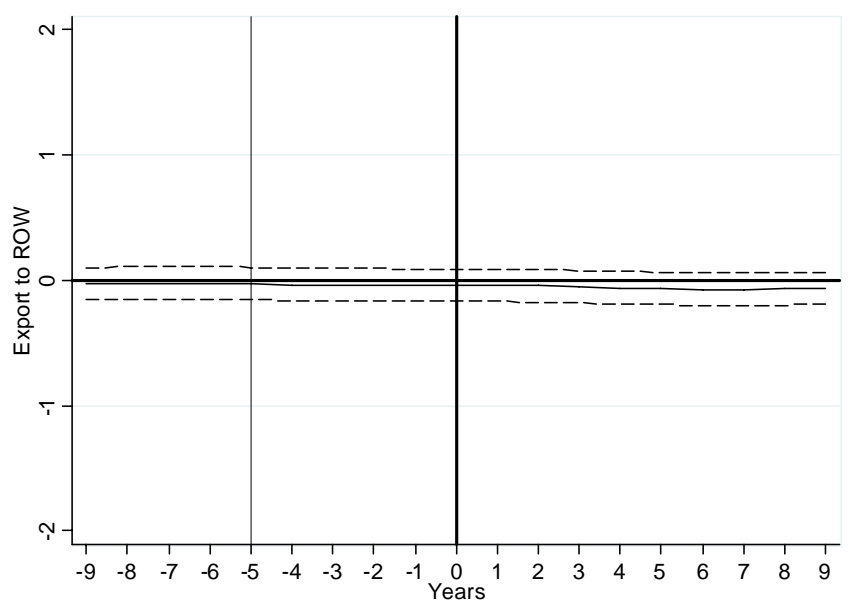

Country-pair and year fixed effects

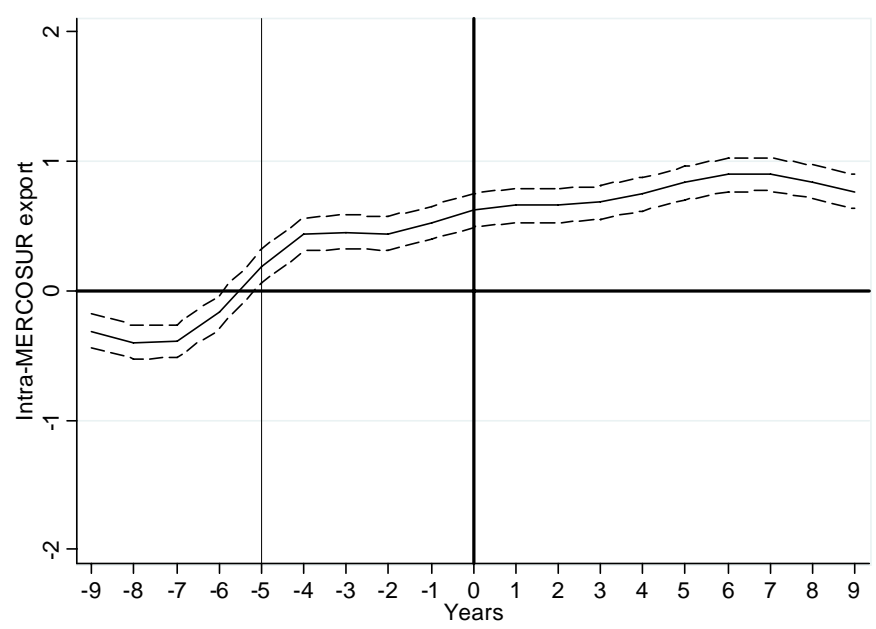

Country-pair and year fixed effects

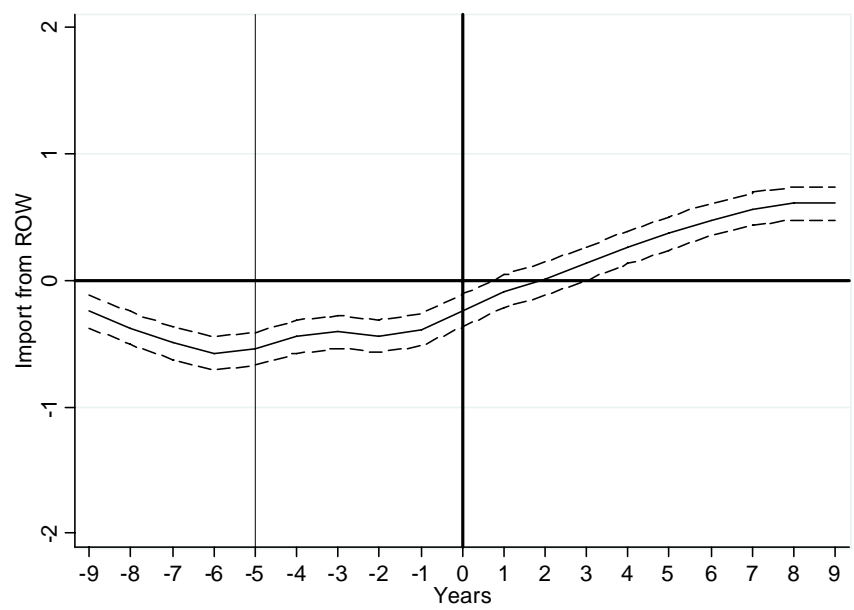

Country-pair and year fixed effects

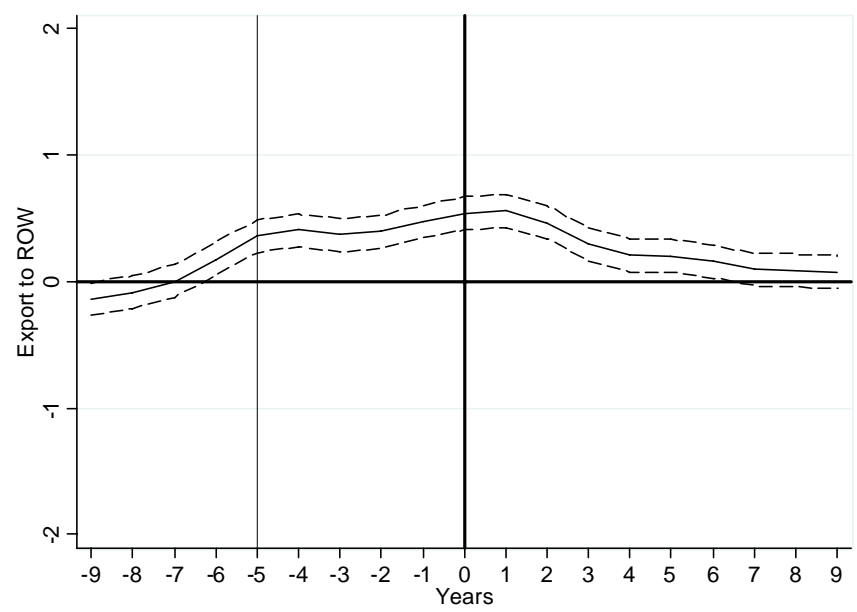

Figure 6: MERCOSUR tradeeffects 
Exporter-time fixed effects

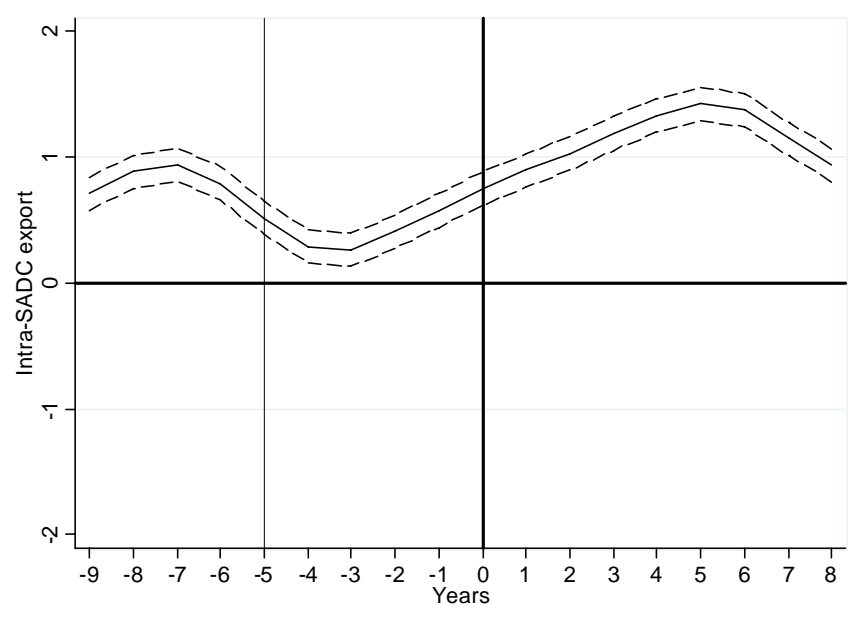

Exporter-time fixed effects

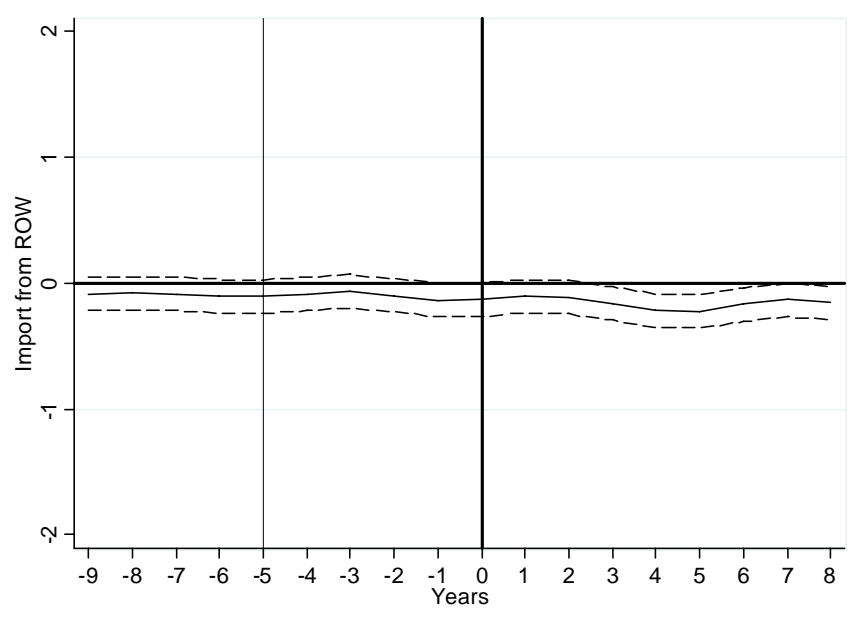

Exporter-time fixed effects

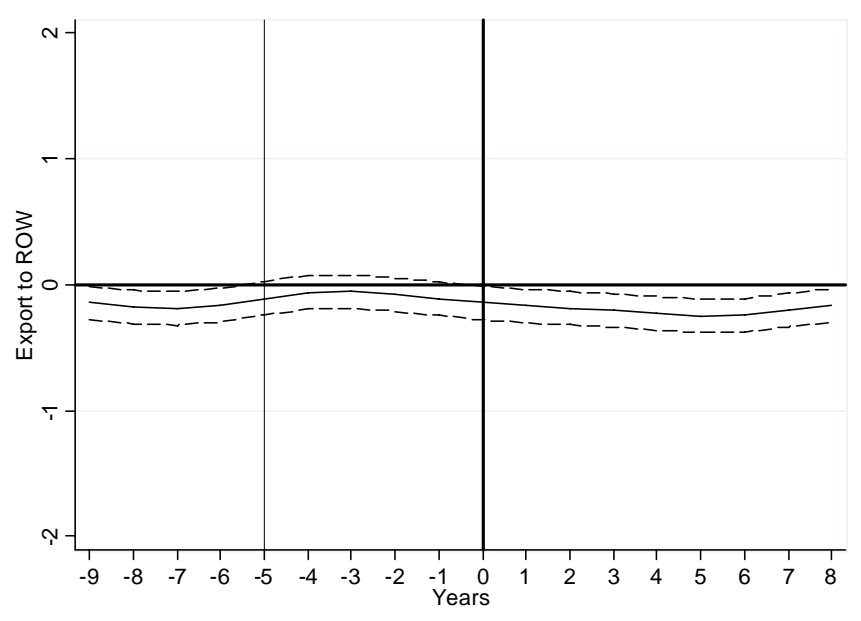

Country-pair and year fixed effects

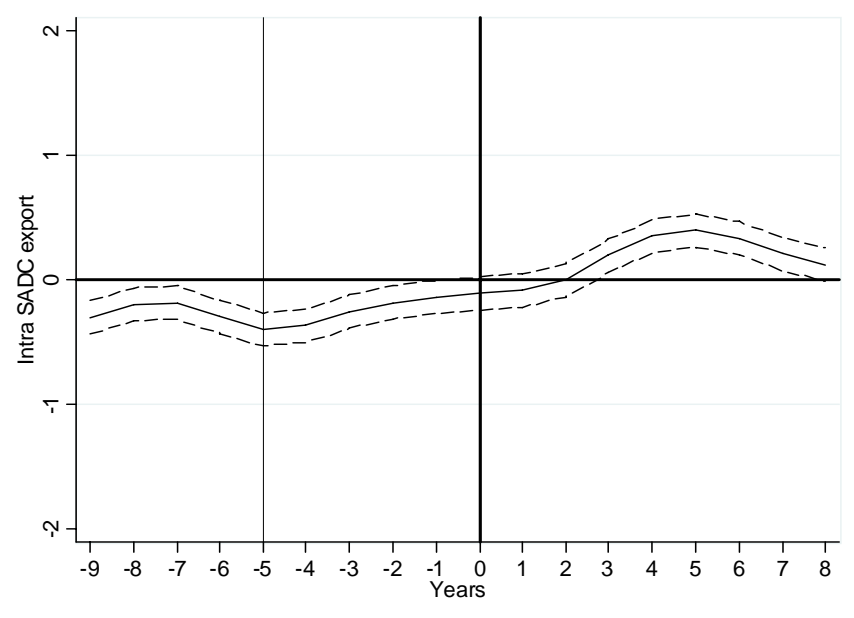

Country-pair and year fixed effects

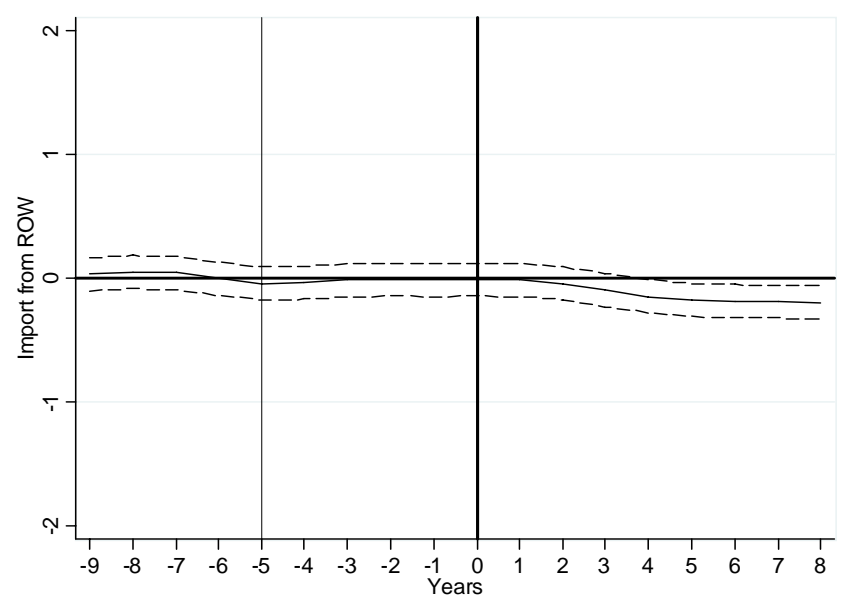

Country-pair and year fixed effects

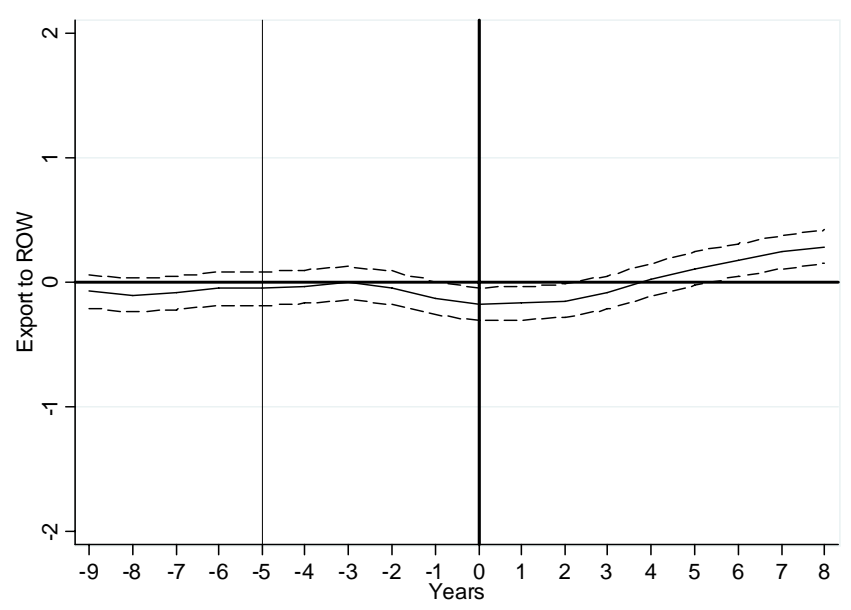

Figure 7: SADC trade effects 

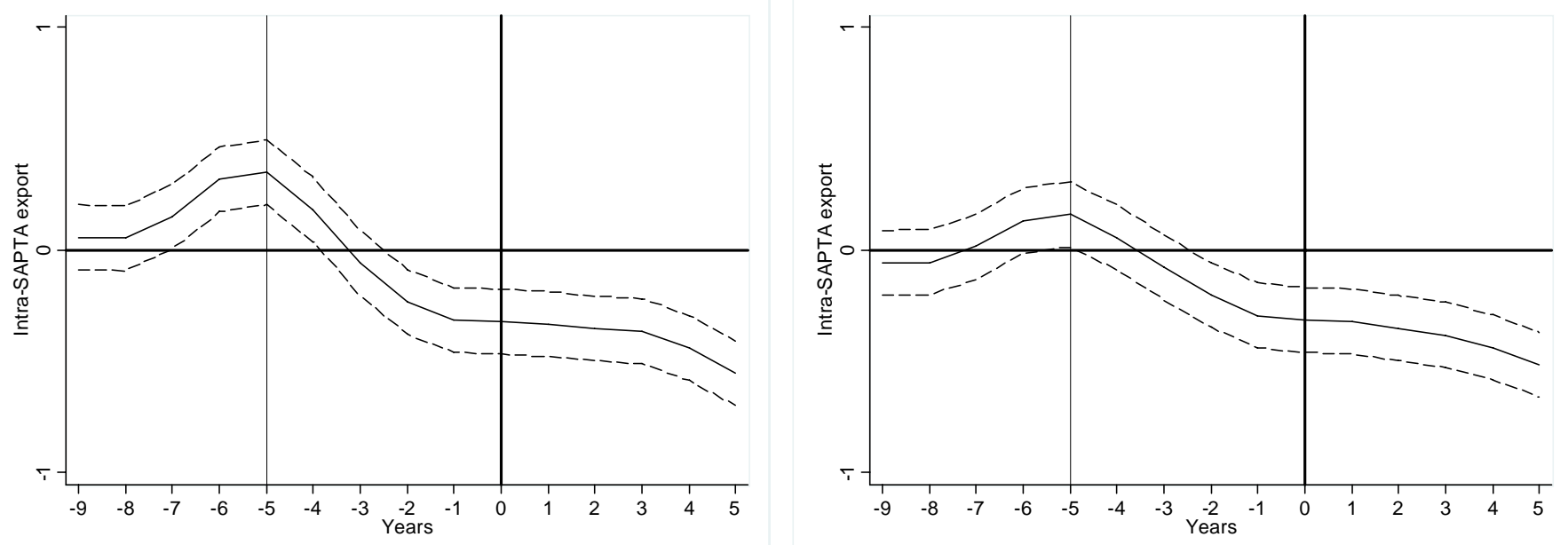

Exporter-time fixed effects

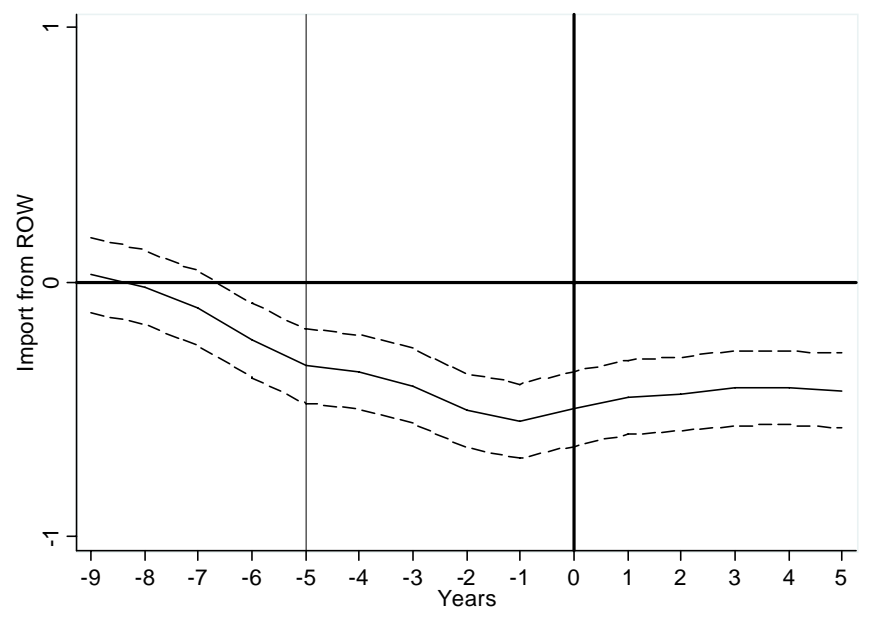

Country-pair and year fixed effects

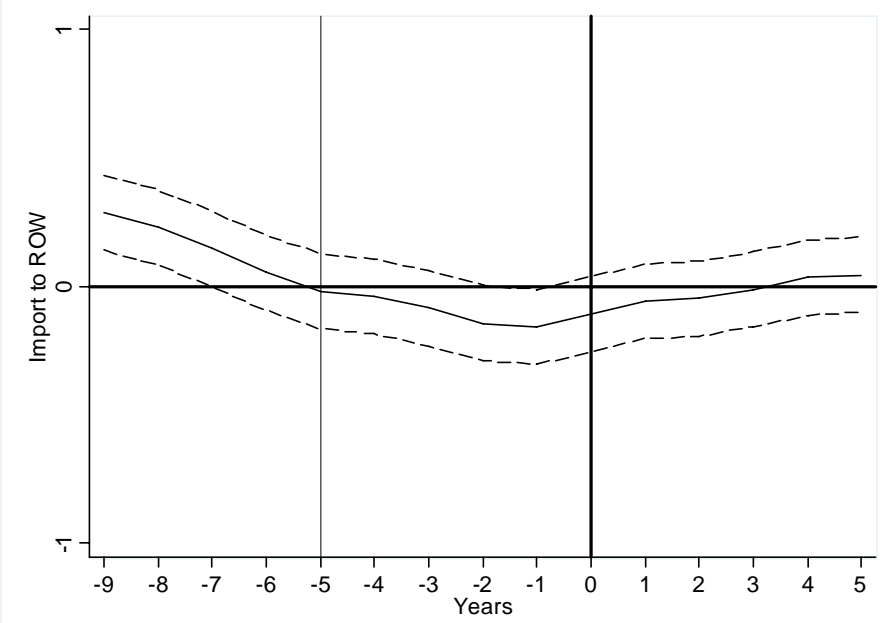

Exporter-time fixed effects

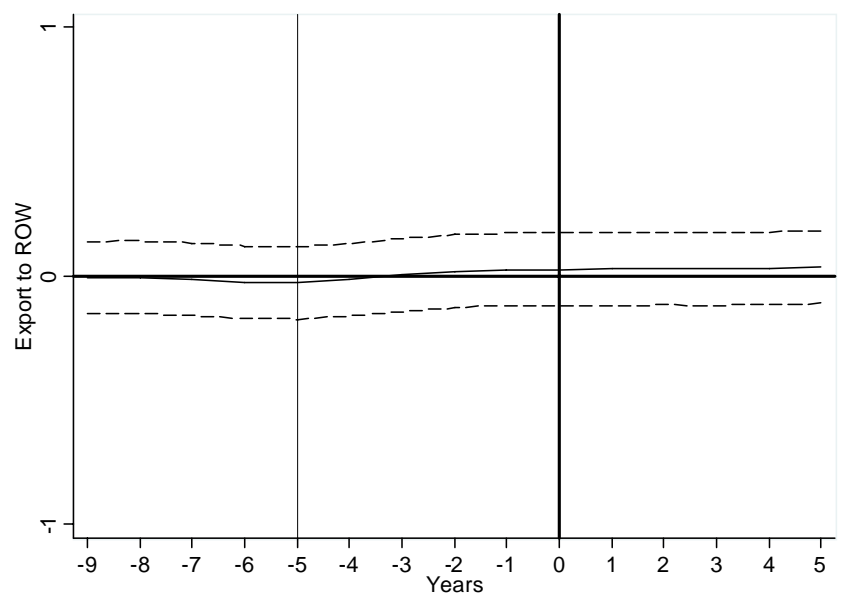

Country-pair and year fixed effects

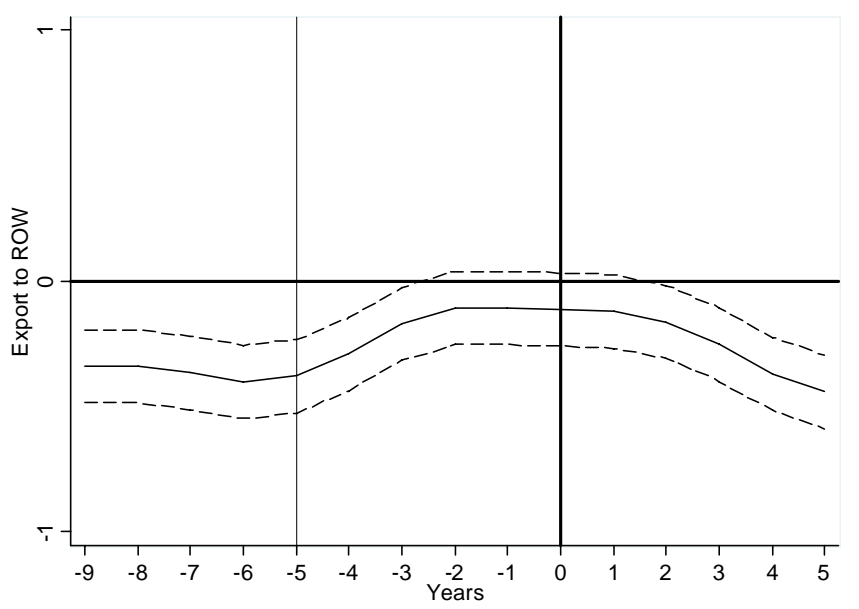

Figure 8: SAPTA trade effects 